\title{
Pedro Gil: o tempo das coisas
}

\author{
ANA PAIS E RUI PINA COELHO
}

Pedro Gil é um actor ímpar. Versátil, vibrátil e minucioso, o seu trabalho de cena tem sido um dos maiores motivos de deleite estético nos palcos portugueses ao longo dos últimos quinze anos. Personagens como Lucky, em À Espera de Godot, pelo Teatro Meridional (2006), as várias construções cénicas de Tristeza e Alegria na Vida das Girafas (2011), de Tiago Rodrigues, ou, num registo menos teatral, Adriano, em Multiplex (2013), de Rui Horta, não deixam margem para dúvidas. Colaborou ainda com outras importantes companhias portuguesas: Artistas Unidos, Bando, Casa Conveniente, mala voadora. Para ele, o trabalho de actor não se distingue da pesquisa que conduz a encenação: «há uma ligação entre o actor que o encenador é e os espectáculos que faz».

Sabe do que fala já que, simultaneamente à sua carreira de actor, Pedro Gil tem assinado igualmente projectos de sua autoria, respeitando um ritmo de criação próprio que resiste, por necessidade e militância, à lógica das carreiras curtas e da produção em série. $O$ caminho iniciado com Homem-Legenda (2005), interpretado por Pedro Carmo, tem por mais recente apresentação uma reescrita do clássico de Molière, Don Juan esfaqueado na Avenida da Liberdade (2018), com um elenco de encher as medidas. Pertencendo a uma geração que beneficiou de contextos de formação não tradicionais em Portugal, que ainda rareiam, Pedro Gil encara o mundo e os modos de fazer teatro com uma curiosidade insaciável na sua potência inigualável de celebrar a vida, paradoxalmente «bela» e «ridícula». Nesta entrevista, Pedro Gil fala-nos desta vida bela e ridícula, da sua formação e percurso, das suas referências teatrais, do seu projecto de cinema e das condições de fazer teatro hoje em Portugal. 
Podíamos começar pelo espectáculo Homem-Legenda [2005]. Terá sido o primeiro momento onde tens uma visibilidade pública mais notória. Foi um espectáculo que quando estreou foi muito bem recebido pelos pares. Queres voltar a esse espectáculo e perceber se há nele alguma génese criativa, alguma formulação mais estruturada sobre a tua ideia de teatro?

O Homem-Legenda foi a minha terceira tentativa de fazer qualquer coisa para um público [depois de Alvo Branco, 2004, e Execução Pública, 2005] e todas surgiram depois da primeira edição do Curso de Encenação do Programa Criatividade e Criação Artística da Gulbenkian, com o Alexander Kelly. De todas as experiências de formação que já tinha tido na área da encenação e da criação para teatro, essa foi a mais sistematizada, a mais intensa, a mais absorvente, a mais revolucionária e a mais feliz. O Homem-Legenda é um espectáculo, de facto, com mais visibilidade, talvez porque tenha tido o meu maior apoio financeiro até então, com estreia no palco do CAM [Centro de Arte Moderna], com o tal reconhecimento do público de que falam. E até da crítica. Lembro-me de ler a minha primeira crítica impressa num jornal, do Augusto M. Seabra no Público. A reacção das pessoas foi tão entusiástica que fizemos mais um mês e meio no Trindade e ainda uma digressão por mais de dez teatros. Foi um processo muito feliz com o Diogo Mesquita e o Pedro Carmo, a Rosinda Costa, o Pedro Silva, o Sérgio Milhano e, claro, a Ana Pereira. Olhando em retrospectiva, identifico nele uma ideia de teatro, mas não é nada que eu buscasse à partida nem é algo que eu busque, creio que não há uma ideia de teatro por espectáculo, cada espectador descobre a sua. Julgo que é mais frutuoso encontrá-la a cada noite do que procurá-la.

\section{O Homem-Legenda é, portanto, uma espécie de arranque?}

Fui desde sempre um espectador ávido. Os filmes e os livros sempre tiveram uma grande relevância na minha vida, e por isso é difícil discernir onde tudo terá começado. Como artistas, creio que somos sempre, pelo menos na escrita e no teatro, enquanto encenadores, enquanto actores, enquanto escritores, muito autodidactas. Não é tão linear como tirar a carta de condução e depois começar a guiar. Não há propriamente um sítio onde se vá aprender a escrever romances ou peças de teatro ou aprender a encenar, ou há? Não estou a dizer que devia haver, há coisas salutares nessa ignorância, nessa falta de conhecimento técnico, 


\section{Amo-te}

HOMEM-LEGENDA, DE PEDRO GIL, 2005, BARBA AZUL (PEDRO CARMO), [F] EMÍLIA ROSA 

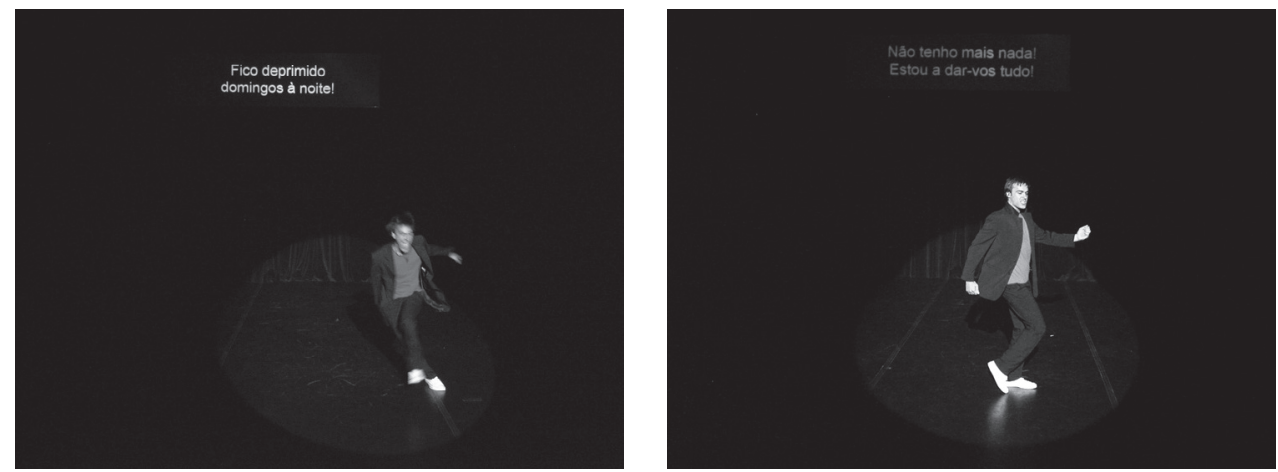

HOMEM-LEGENDA, DE PEDRO GIL, 2005, BARBA AZUL (PEDRO CARMO), [F] EMÍLIA ROSA

nessa ausência de ferramentas, há um «ter de inventar uma língua nova cada vez que se quer falar» que é louco e estúpido, mas que também pode ser muitas outras coisas. Durante todo esse tempo, eu ia tentando como se tenta quase sempre, primeiro no esconderijo da cabeça e depois estendia-o através da escrita. Exercitava a minha imaginação através da escrita, uma ideia, uma cena, um argumento para cinema, uma frase, um projecto, um filme, uma imagem, um espaço cénico, uma música, pontos de partida a trabalhar com os actores, um processo, reflexões ou crítica sobre outros espectáculos que via. Mas era uma coisa que eu fazia para mim e guardava para mim. Via os meus amigos colegas do conservatório darem o passo seguinte, mas eu não o conseguia dar.

Depois houve qualquer coisa naqueles dias que passei com aquelas pessoas ali [no curso de encenação da Gulbenkian] e com aquele homem [Alexander Kelly] que me transformou, ou que muito simplesmente me ajudou a encontrar o que faltava para esse arranque. $O$ curso da Gulbenkian foi importante porque aquilo que o Alex propunha nas aulas, a experimentação que fazíamos, a discussão à volta do que fazíamos, fez-nos criar matéria cénica a partir de pontos de partida e de formas que a maioria de nós nunca tinha antes experimentado. Não que fossem inovadoras, nós é que não tínhamos experimentado. O Homem-Legenda surge depois disso.

Disseste uma coisa curiosa: «não se pode aprender a escrever, não se pode aprender a encenar», mas ao mesmo tempo tens falado da experiência do curso com o Alexander Kelly como uma experiência feliz e que te deu, depreendemos, muitos instrumentos. Achas que isso tem que ver, como agora disseste, com o modo 
como constróis a cena? Talvez o lado de encenador que não se aprende é aquele de procurar, é aquele que tem uma visão. E ter uma visão, realmente, não se pode ensinar a ninguém. Mas um lado do fazer, dentro da perspectiva que é muito dramatúrgica de trabalho do Alex, amplia o espectro de possibilidades do que é construir essa cena. Não sei se concordas connosco ou se consegues identificar alguma coisa...

Não é incoerente com aquilo que eu estava a dizer. Na verdade, o Alex não nos ensinou nada. Nunca nos disse que o teatro é isto, ou que devem fazer assim. Ele, com toda a sua gentileza e graça, propunha experiências, exercícios, e nós fazíamos. A seguir falávamos e discutíamos, e cada um sistematizava para si o que tinha acontecido. Só isso... Era o paraíso. Durante três meses. E foi assim que, em vez de nos ensinar, nos deu a aprender. E ele podia nem sequer dar a sua opinião; a opinião dele não era o mais importante. Não consigo, ainda hoje, imaginar um modelo de escola melhor. No fundo, é uma plataforma de experimentação num ambiente de confiança, onde tudo é possível, nada está errado e tudo se discute. É óbvio que tem de se tirar o chapéu ao Alex nos exercícios que ele propunha, nas perguntas que formulava e no ambiente que proporcionava. A minha experiência como actor ainda era pouca, só comecei a ver teatro com dezoito anos - tinha ainda muito tempo perdido para recuperar-o que tinha visto ou estudado pouco era, e uma das coisas que o Alex nos deu a perceber é que tudo é possível. Sim, alargou a ideia que tínhamos de como se pode fazer teatro, há muitas formas de fazer a mesma coisa, há imensas coisas que são possíveis e nós não sabíamos que eram possíveis. Apesar da minha elevada ignorância, só por isto, ele foi um grande mestre.

\section{Muito material que não se entendia como matéria?}

Mostrou-nos que as formas de gerar material e de o trabalhar cenicamente são ilimitadas, as fontes são ilimitadas, podemos ser nós a inventar os processos, até as ferramentas, e que formalmente vale tudo. Esta liberdade poderia oprimir-me, mas teve o efeito contrário.

\section{Isso para ti esteve sempre associado a escrever também para cena?}

Usamos o verbo escrever como quem diz desenhar, no sentido em que se pode dizer escrever a luz ou desenhar o som, ou até desenhar as letras. 
É como quem diz criar. É muito curioso isso. E não é por acaso que o fazemos. Diz-se escrever quando muitas vezes nem se escreveu. Existem pessoas como o João Brites que nos seus guiões escreve tudo e mais alguma coisa (luz, cenário, adereços, sonoridades, acções, subtextos, premissas para o actor, a duração das cenas, enfim) ao que podemos chamar de guião de encenação; outros como o Jorge Silva Melo, que escreve da sua cabeça apenas aquilo que os actores vão dizer, o que normalmente entendemos por peça de teatro, outros apenas um alinhamento de cenas ou momentos, e por aí fora. Eu já tinha trabalhado com o Brites, com o Silva Melo, com a Mónica Calle e com o Miguel Loureiro, logo depois com o Jorge Andrade e com o Miguel Seabra. Tinha a experiência de quem está de dentro, via como eles «escreviam» e como cada um o fazia à sua maneira. Mas havia uma coisa que eu não conseguia ver, era esse vai-e-vem invisível que vai da cabeça para a mão que escreve e volta e torna a ir. Tenho um impulso criativo, mas como é que o torno cena? Portanto, é esse salto para «mas como é que eu crio cena?», «como é que eu materializo as minhas ideias cenicamente?». A resposta é simples: fazendo. Mas eu não conseguia, muito menos escrever palavras para serem ditas por actores. E era isso o que eu procurava, ser capaz de inventar uma realidade, criar a minha cena e não encenar peças de outros, isso eu já sabia o que era e gostava de fazer como actor. E sim, grande parte do trabalho de encenar um espectáculo, para mim, consiste em escrever. Escrever para os meus espectáculos é das coisas que mais gosto de fazer, às vezes até me dá mais gozo do que actuar.

\section{Esse momento, o da formação com o Alexander Kelly, tem sido identificado por muitos artistas que o frequentaram como um momento de viragem.}

Foi maravilhoso, era como um parque de diversões onde podíamos brincar à vontade. Nunca mais eram nove da manhã do dia seguinte para voltar para lá. E depois, claro, durante as tardes víamos filmes, mostrava-nos vídeos de espectáculos a que dificilmente teríamos acesso. O Alex abriu-nos portas para alguns textos, filmes e artistas aos quais eu não tinha acesso, deu-nos acesso a um conhecimento que não estava à venda e que eu jamais iria encontrar sozinho. 


\section{Houve depois um grande período em que estiveste a trabalhar mais como actor. O Mona Lisa Show aparece em 2008. Porquê tanto tempo entre uma coisa e outra?}

Por um lado, foi o tempo que precisei para fazer o Mona Lisa Show. Por outro lado, a vossa pergunta pode depreender que três anos é muito ou que as pessoas precisam de ver uma peça minha pelo menos uma vez por ano, mas não é assim, o mundo não parou de girar. Nós estamos habituados a que o artista em teatro faça duas ou três criações por ano, mas o meu ritmo é nitidamente dos dois anos para cima. $\mathrm{E}$ o que quer isso dizer? Quer dizer que é o tempo que preciso, só isso. A minha dificuldade está em manter esse ritmo na perspectiva do mercado, dos financiamentos, do olhar crítico e do público. Depois do Homem-Legenda fui convidado a acelerar, mas percebi logo que não ia ser feliz a fazer um espectáculo todos os anos, ou dois espectáculos por ano, e portanto disse que não. Embora eu também não separe o trabalho de actor do trabalho de encenador, no sentido em que para mim tudo faz parte da mesma prática.

\section{Mas foi consciente essa tomada de decisão, do ritmo?}

Sim, pensei: «Não vou conseguir, não vou ser feliz, e não é para mim.» Passados uns anos, o Giacomo [Scalisi] seduziu-me para um projecto e eu disse então que sim. Disse que sim porque estava pronto.

Essa é uma das coisas que mais mina a produção e a criação, em Portugal e não só, em todo o lado. É a confusão entre a urgência artística de fazer coisas e a obrigação de ter de fazer daquela maneira ou naqueles ritmos.

Há pessoas que são felizes assim e que o fazem de forma saudável. Até há quem precise disso, pessoas cujo trabalho assenta precisamente nisso. Eu não. Para mim seria como chegar de uma grande viagem, ainda mal desfizeste as malas, ainda nem mostraste os slides que tiraste e já estás a embarcar de novo. Que canseira. Tenho receio de que, ao trabalhar assim, aquilo que faço se torne demasiado sobre aquilo que já fiz, ou sobre aquilo que continuamente não paro de fazer. Preciso de algum tempo para deixar a vida entrar. A relação da criação com a produção, com vista a uma exibição, é e será sempre um problema para todos os 
artistas. Qual o tempo das coisas? Cada um gere isso da melhor maneira que consegue. Só o artista amador é verdadeiramente livre, só ele é que não está dependente do dinheiro e se pode dar ao luxo de terminar a sua obra, ou de a deixar em aberto. Todos os outros têm de a mostrar na data marcada.

\section{Mas também porque ias tendo muito trabalho como actor?}

Claro, e conseguia viver disso. Mas uma coisa não abafou a outra, não compete com a outra. Para mim os trabalhos que faço como actor, as co-criações que fiz com outros criadores, as peças que encenei, os espectáculos para os quais escrevi, tudo se insere na mesma lógica. Faz tudo parte da minha prática, é o mesmo ofício. Para mim, a peça que fiz com o encenador X é tão parte da minha «obra» como o Don Juan que acabei de encenar.

\section{E tu tens personagens bastante marcantes!}

Não estou aqui a dizer que somos todos uma companhia de teatro e que fazemos todos parte de uma grande família. Estou a dizer que é assim que me posiciono e me vejo nesta profissão. Estou neste ramo: interpretar, encenar, escrever, desenhar um cenário tem tudo a mesma importância, uma coisa não vale mais que a outra. É tudo teatro. Trabalho sempre no mesmo sentido.

\section{Qual é esse sentido?}

Talvez seja um fazer, uma procura no fazer que procuro levar e aprofundar de cada vez que salto para um novo projecto, uma procura que em grande parte parece nascer da pergunta: o que é que o teatro pode ser? Claro que às vezes há pessoas e projectos que não me permitem continuar essa procura e, quando assim é, digo para mim: «Não volto a trabalhar com esta pessoa ou nesta condições.» Mas, apesar de tantos saltos de um lado para o outro, isso é raro.

Quando dizes que o teu ritmo de criação precisa de dois anos para cima entre cada espectáculo, estamos a pensar em objectos muito concretos: os espectáculos em que te situas como encenador, como escritor, como autor. Não te obrigas a ficar dois anos à espera de 
trabalhar como actor. Sendo a mesma coisa, são objectos de um percurso que ocupam importâncias e relevâncias diferentes, nãoé?

Talvez a importância não deva então ser medida pelo tempo. Não estou a dizer que não há diferença entre ser actor e ser encenador, o que me interessa é sublinhar a ideia de que ambos são autores e ambos estão, cada um na sua função, a fazer teatro, o mesmo teatro. Um não é mais nobre que o outro. Se durante anos trabalhei mais como actor, isso não quer dizer que os trabalhos que fiz como encenador não fossem igualmente importantes, e vice-versa. Senão, seria o mesmo que dizer que só sou actor para ganhar dinheiro, para comprar tempo para finalmente fazer aquilo que gosto, para poder encenar as minhas peças. Eu não sou encenador em part-time. Aquilo de que gosto é disto tudo. Fazer teatro foi uma das formas que arranjei para viver com os outros e tudo isto faz parte desse fazer.

\section{A importância ou grau de responsabilidade?}

O grau de responsabilidade no qual me empenho como actor devia ser idêntico de quando estou a encenar. Quando tal não acontece, há razões para isso, nem que seja «o que eu queria mesmo estar agora a fazer era encenar». Mas o tempo não conta para nada, uma relação de uma noite e uma relação de dez anos podem ser, apesar de diferentes, igualmente maravilhosas. Ambas têm o seu lugar e não competem uma com a outra.

\section{Mas há alguma personagem que tenhas como mais querida?}

Do passado?

Sim, que tenhas feito. Estou a pensar nas tuas favoritas. Estou a lembrar-me do Lucky, do À Espera de Godot, do Teatro Meridional... Estou a lembrar-me também, apesar de ser noutro estilo, na Tristeza e Alegria na Vida das Girafas, do Tiago Rodrigues. Um registo completamente diferente.

Para mim tenho, claro. Tantas. Se estão com tempo, aqui vai... Essas foram muito especiais, o Brian do Shopping and Fucking também, talvez a primeira encenação do Gonçalo Amorim, o Pinard da Bovary, também 


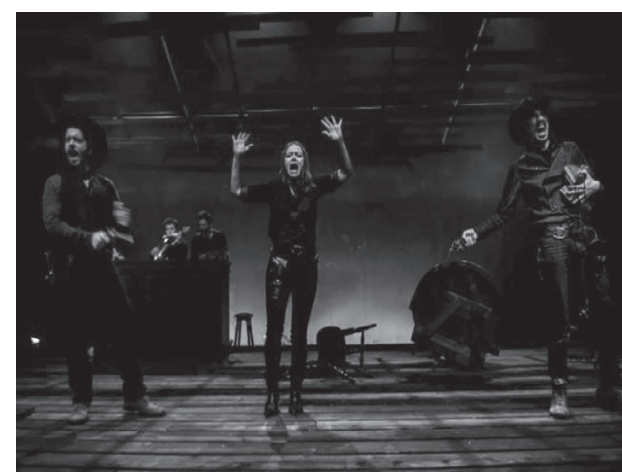

CASA VAGA, CO-CRIAÇÃO GONÇALO AMORIM, PEDRO GIL, RAQUEL CASTRO E RUI PINA COELHO, TEXTO DE RUI PINA COELHO, ENC. GONÇALO AMORIM, PEDRO GIL, RAQUEL CASTRO, TEP - TEATRO EXPERIMENTAL DO PORTO (PEDRO GIL, RICARDO NOGUEIRA, JOÃO ROSÁRIO, RAQUEL CASTRO, GONÇALO AMORIM), [F] PAULO PIMENTA

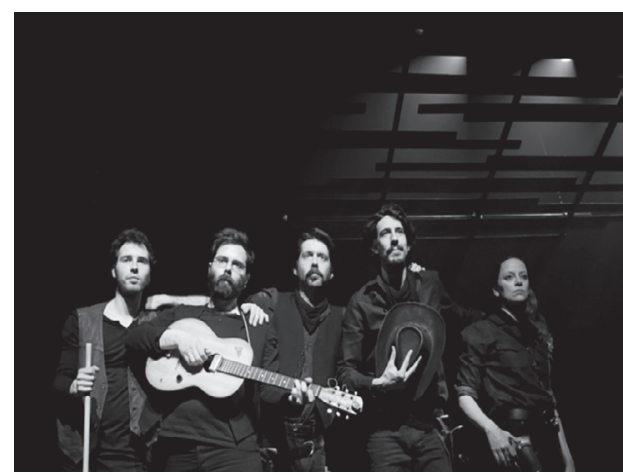

CASA VAGA, CO-CRIAÇÃO GONÇALO AMORIM, PEDRO GIL, RAQUEL CASTRO E RUI PINA COELHO, TEXTO DE RUI PINA COELHO, ENC. GONÇALO AMORIM, PEDRO GIL, RAQUEL CASTRO, TEP - TEATRO EXPERIMENTAL DO PORTO (PEDRO GIL, RICARDO NOGUEIRA, JOÃO ROSÁRIO, RAQUEL CASTRO, GONÇALO AMORIM), [F] MAFALDA LENCASTRE

do Tiago Rodrigues. Depois os trabalhos que tenho feito com o Rui Horta, o Multiplex, a partir das Memórias de Adriano, e o Estado de Excepção. A minha primeira vez também foi especial, era um Don Juan escrito pelo Pedro Saavedra. O rapaz das flores de Onde vamos morar, texto do José Maria Vieira Mendes, encenação do Jorge Silva Melo. O Casa Vaga, que fiz contigo [Rui Pina Coelho] lá em cima [TEP - Teatro Experimental do Porto]. A Mariana, que fiz n'O Bando, encenação do João Brites, foi muito especial, ainda hoje não sei o tanto que aprendi com a Teresa Lima. Os Anjos, também no Bando, em que fui fazer uma substituição a uma semana da estreia. Dias inteiros com o Luca Aprea a aprender o espectáculo. Ainda hoje, sempre que entro em cena, a Teresa e o Luca estão de alguma forma ali comigo. A experiência do Esboço, do Miguel Loureiro, Os Justos, com a mala voadora, encenação do Jorge Andrade, os Grandes Sinais, da Rita Calçada Bastos. Não me posso esquecer do Iago que fiz com a Letizia Quintavalla, claro, o Enquanto Vivermos que fiz com o Romeu Costa, o Inimigo do Povo encenado pelo Tónan Quito, O Nosso Desporto Preferido, do Gonçalo Waddington, mais recentemente o Pedro e o Capitão, encenado pela Marta Carreiras e pelo Romeu. Tantas...

\section{E porquê? Porque destacas essas?}

Essa talvez seja uma das perguntas mais difíceis de responder. Tão difícil como tentar perceber porque corre mal quando corre mal. Posso pensar aqui nalgumas hipóteses. Porque de alguma forma me realizei. Às vezes 
é quando tudo levanta dois centímetros do chão. Pode ser uma espécie de harmonia que acontece entre o objecto, o espectáculo e aquilo que estou a fazer, entre mim e tudo o resto que me é estranho, o material, o público, os outros actores. Às vezes é quando consigo alcançar um determinado «estar» em cena. Não sei, se calhar também tem que ver com a surpresa, com descobrir uma coisa nova, chegar a um sítio novo, é isso. Também pode ter que ver com composição. Quando chego a um lugar de composição onde nunca tinha estado antes. Ao passo que existem outros projectos em que chego ao fim e penso: «Já sabia que ia chegar aqui.» Outra coisa não menos importante, e agora vou revelar um grande segredo da profissão, é que todos os actores mentem quando dizem que gostam de fazer personagens que não têm nada que ver com eles. O que eles gostam é de fazer personagens que falem deles, mas não daquilo que já todos sabemos acerca deles, mais daquelas coisas que ninguém sabe, às vezes até coisas que o próprio não sabe. Por isso quando virem um actor a ir muito bem no papel de Ricardo III, o meu conselho é: desconfiem. Mas não sei, vou pensar nisto.

\section{Tens uma metodologia de trabalho de actor em que vais afinando ou cada processo impõe uma gramática de composição diferente?}

Como trabalhei com encenadores muitos diferentes e sempre fui desafiado para fazer as coisas de maneira muito diferente - isso em si é toda uma outra escola-, não me é possível sequer ter uma metodologia rígida. Gosto quando me ligam a dizer: «Vem fazer esta viagem comigo.» Acho que isso é lindo, é lindo confiar e ir atrás, ajudar essa pessoa fazendo da sua viagem a minha viagem. Quando entro num projecto, é para o servir e a melhor forma é fazer dele o meu projecto. Penso que o desafio é: como é que eu me ponho ao serviço do espectáculo mas à minha maneira, enquanto actor-autor? De outra forma também não seria possível, só sei fazer as coisas à minha maneira...

Acho que houve de tudo: pessoas que me propuseram um processo e depois pessoas que dão muita autonomia e que é esse o processo. Depende de facto do projecto e do momento da minha vida e principalmente das pessoas com quem partilho o palco, é um trabalho colectivo também. Essa é que é a graça, é um trabalho individual e colectivo ao mesmo tempo, com os outros actores, com o encenador, se houver, com as outras componentes do espectáculo. Às vezes é o texto que guia mais, às vezes pode ser uma cenografia, outras, uma lógica de jogo. Há obviamente coisas 
que são comuns: o trabalho de análise de texto. A componente física do espectáculo, no sentido em que o espectáculo é uma actividade que tem uma dimensão física, tem uma dimensão atlética até se quisermos, de expressão, estar duas horas à frente de um público a tentar comunicar qualquer coisa, muitas vezes aos pinotes, é de ficar sem ar. Decorar o texto, quando há texto, ou a coreografia se houver coreografia. E muitas outras coisas.

Não temos dados estatísticos para confirmar isto, mas imaginamos que sejas dos actores da tua geração que tenha trabalhado com uma paleta mais diversa de criadores, dos herdeiros do teatro independente, como os Artistas Unidos, ou com os teus camaradas de geração, digamos assim. Tens na tua posse um olhar muito privilegiado para fazer uma espécie de mapa, para mapear o caleidoscópio que isto tudo é. Tens experiências diversas, com esta gente toda?

Querem que faça aqui a minha história do teatro contemporâneo português?

Não necessariamente isso, mas tens um olhar sobre o nosso teatro que é muito completo. Trabalhaste com várias gerações de criadores, com actores mais novos, dirigidos até por ti, por exemplo, com os teus camaradas de geração, como o Gonçalo Amorim ou o Tiago Rodrigues, tens trabalhado com encenadores mais seniores, como o Jorge Silva Melo, o Rui Horta, o João Brites. tens, portanto, um olhar muito transversal em relação ao mapa da criação portuguesa contemporânea. Já pensaste nisso? É uma coisa que foi acontecendo?

No fundo, estou muito grato, por ter trabalhado com gente tão diferente e de gerações tão diferentes. Grato em primeiro lugar por ter trabalhado com alguns dos fundadores do teatro que herdei - além de ter feito parte da última turma do João Mota no Conservatório -, estou obviamente a falar do João Brites e do Jorge Silva Melo, claro, mas também dos actores com quem eles me deram oportunidade de trabalhar, o Horácio Manuel, a Paula Só, o João Perry, a Lia Gama, o Sérgio Godinho, apenas para nomear alguns. Isso foi para mim muito importante, foram pessoas com quem aprendi muito e que apostaram em mim, tão importante que me pergunto o que teria sido da minha vida se não tivesse tido 

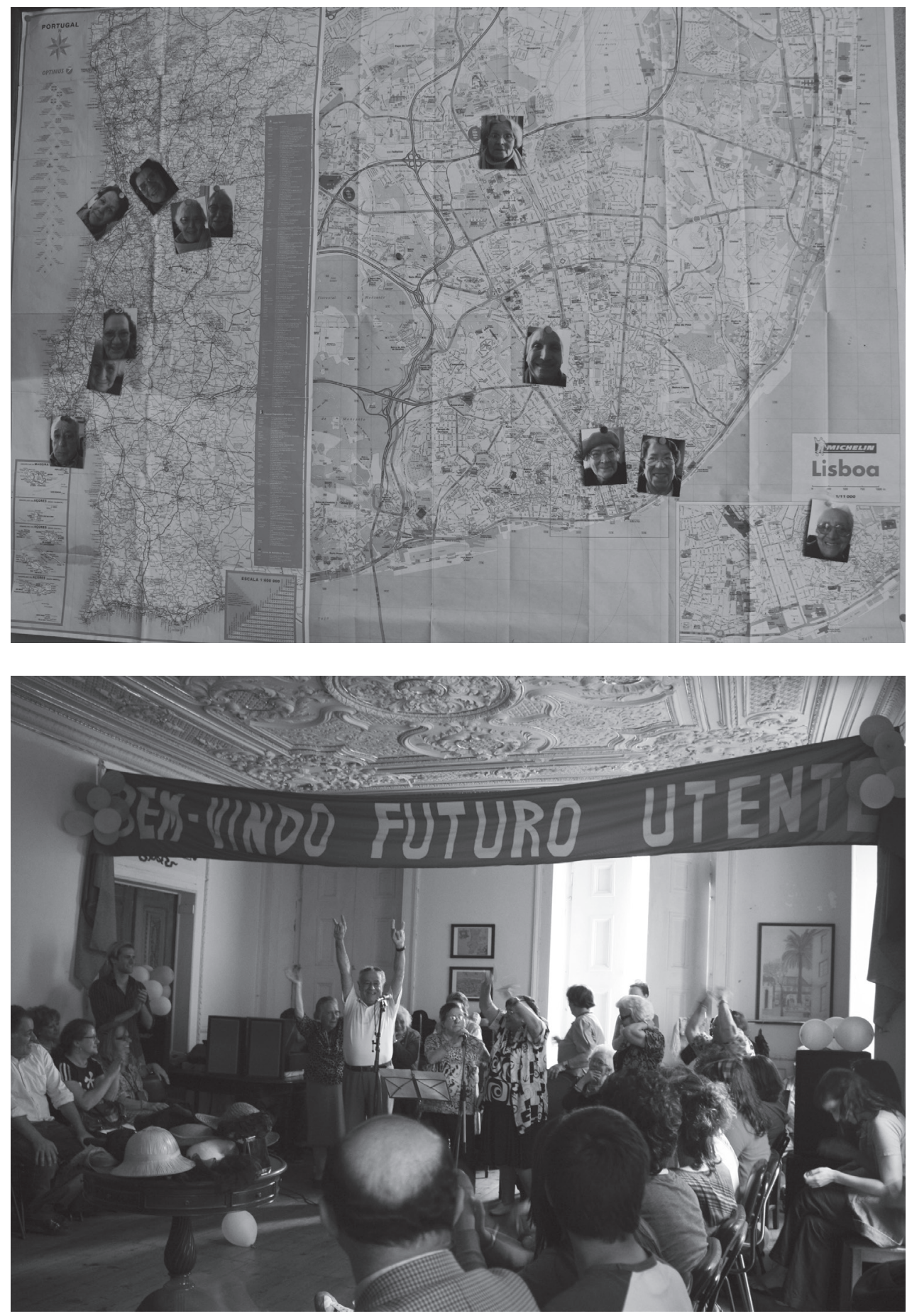

CENTRO DE DIA, CO-CRIAÇÃO ANA BIGOTTE VIEIRA, ANA PEREIRA, IRIS CAYATTE, FREDERICO LOBO, PEDRO GIL, RAQUEL CASTRO, ROMEU COSTA, SUSANA CECÍLIO, COORDENACุÃO GONÇALO AMORIM, 2010, DONA VLASSOVA AND GUESTS E ANAPEREIRA.PEDROGIL (BARBA AZUL), [F] MARIANA C. SILVA 


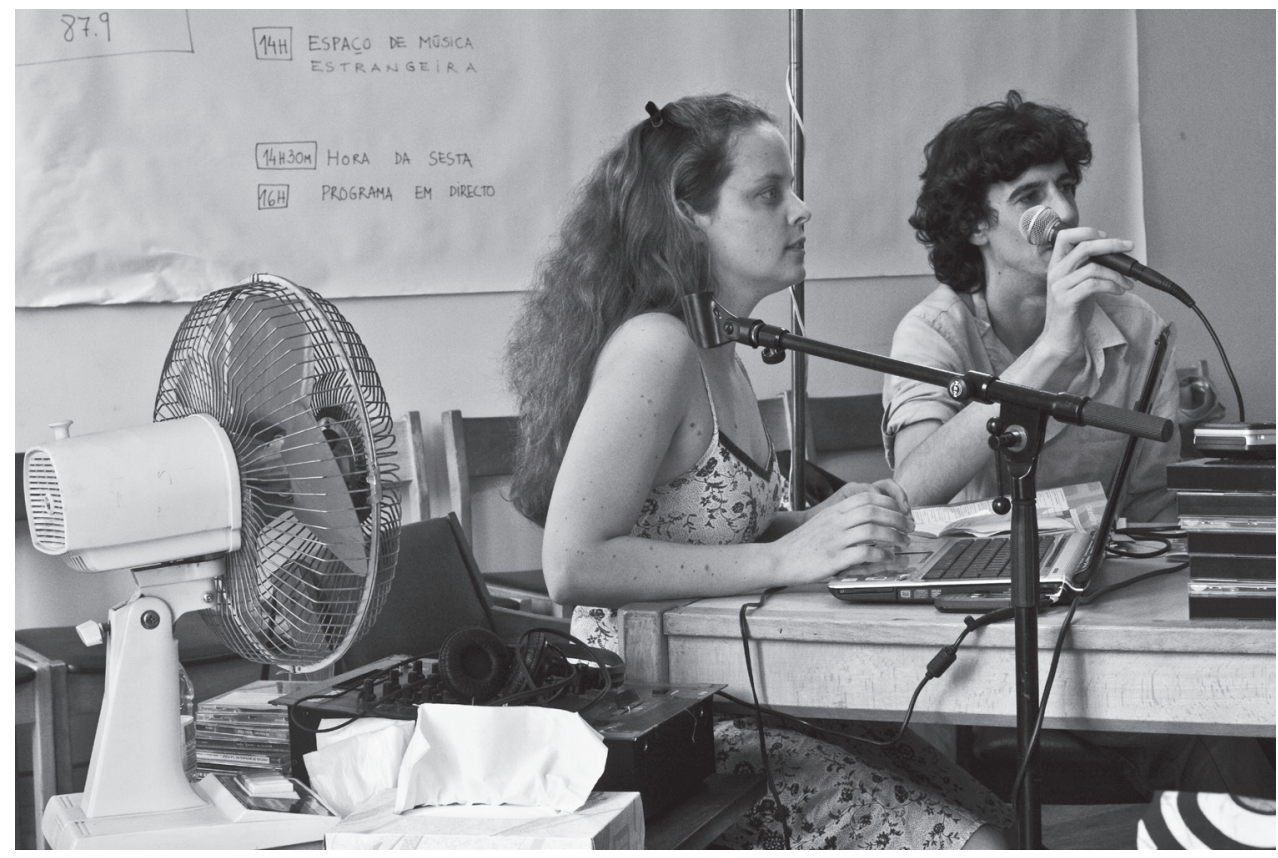

CENTRO DE DIA, CO-CRIAC̣ÃO ANA BIGOTTE VIEIRA, ANA PEREIRA, IRIS CAYATTE, FREDERICO LOBO, PEDRO GIL, RAQUEL CASTRO, ROMEU COSTA, SUSANA CECÍLIO, COORDENAC̦ÃO GONÇALO AMORIM, 2010, DONA VLASSOVA AND GUESTS E ANAPEREIRA.PEDROGIL (BARBA AZUL), (SUSANA CECÍLIO, GONÇALO AMORIM), [F] MARIANA C. SILVA

essa oportunidade. Tantas vezes olho para colegas meus, não só os mais novos, e penso: «Que pena que não tiveram essa oportunidade», não no sentido de serem menos actores por isso, ou no sentido de terem de obrigatoriamente de passar por ali, porque o facto é que não têm, tanta gente com quem eu não tive a oportunidade de trabalhar e que gostava, mas mais no sentido em que recomendamos fervorosamente a alguém uma praia que nos é tão especial. Digo isto, mas eles ainda estão vivos, ainda todos podem trabalhar com eles... Como também sou capaz de dizer o mesmo em relação a pessoas das outras gerações que se seguem, o Miguel Loureiro, o Miguel Seabra, a Mónica Calle, o Nuno Cardoso ou o Rui Horta, que pertencem à geração seguinte, com quem tanto aprendi também e que tanto apostaram em mim, ou em relação às pessoas próximas da minha idade com quem trabalho de forma mais promíscua: convido, sou convidado. O Amorim, o Rodrigues, o Tónan, o Waddington, a Raquel Castro, o Jorge Andrade, o Mickael [de Oliveira], o Castro Caldas, com todos aprendi e continuo a aprender. Eles também são os meus mestres. 
Além daquilo que cada um é, a sua personalidade, a sua educação, a sua experiência empírica, talvez consiga identificar uma ou duas coisas que podem ajudar a determinar a forma como cada um faz o que faz. Mas creio que são tudo coisas muito óbvias: a altura em que a pessoa nasce determina, em parte, aquilo que ela vive, o que por sua vez pode influenciar a maneira como encara o trabalho, não só do ponto de vista processual, mas do ponto de vista ético, da hierarquização do poder, e até do ponto de vista estético. Basta pensar no nome «O Bando», que é uma «cooperativa» e que está sediada numa «quinta» no campo, junto a «Palmela», que tem uma forte tradição de esquerda. Depois a sua formação, a sua porta de entrada para o teatro, enquanto o Brites estudou gravura, o Silva Melo estudou cinema e literatura, o Miguel Seabra estudou teatro, fez um curso de formação de actores, e o Rui Horta costuma brincar dizendo que é um arquitecto frustrado. $\mathrm{E}$ depois, esta talvez menos óbvia - e que a mim mais me entusiasma -: penso que o actor (ou não) que a pessoa foi também pode influenciar muito a sua procura. Muita da criação, da nossa melhor criação em Portugal, nasceu da frustração de muitos actores, de não se realizarem a ser dirigidos por outros, por «aqueles» outros, «daquela» maneira. E então pensaram: «Vou tentar fazer à minha maneira. Assim. Será que isto é válido? O teatro pode ser isto?» E isto é transversal a todas as gerações, creio. Ou então é um grande disparate.

Mas para mim há uma ligação direta entre o actor que o encenador é, e os espectáculos que ele faz. Sinto isto enquanto fazedor e enquanto espectador. $\mathrm{O}$ actor que sou contribui para a estética dos meus espectáculos, para a minha maneira de construir a cena. Por isso, tantas vezes os encenadores, quando acontece estarem em cena, são a melhor bússola para os outros actores. Tal como os actores que o César Monteiro ou o Chaplin foram tiveram influência na sua forma de realizar. Foram realizadores que realizavam tendo em conta os actores que eram. Eu vejo assim. A cena transpira o actor que o criador é... ou nunca foi. Não acham?

\section{Ou quer ser...}

Seja o que for, é algo que é levado para a cena e que lhe dá singularidade. Uma singularidade estética que, ainda que por vezes não consigamos nomear, apenas reconhecemos. Porque é também através do corpo no espaço e no tempo do espectáculo, na relação com o público, é também através dessa experiência que cada um tem e que é sua, e secreta, que depois cada um à sua maneira vai construindo a sua identidade cénica. 
Outra coisa engraçada ainda, além das diferenças, é perceber aquilo que aproxima todas estas formas de fazer teatro, muitas vezes nem os próprios se apercebem disso. A mala voadora tem muitas semelhanças com o Bando, por exemplo - deixo esta só para adoçar a boca. Eu pelo menos vejo.

Mas no que diz respeito aos actores, à tua geração, há aqui episódios que são determinantes: o ciclo de formação com o Alexander Kelly, a presença dos tg STAN em Portugal, serviu como gatilho para uma geração de criadores dizer: «OK, há metodologias outras de trabalho, outras possibilidades de encontro que não precisam de depender da formação que tivemos.»

Para mim, o curso do Alexander Kelly foi importante, como também foram importantes todas as experiências que tive como ator com as diversas companhias e artistas de teatro com quem trabalhei, bem como todas as pessoas com quem trabalhei nos meus espectáculos. Como também foi importante ter visto o Platonov dos STAN [Point Blank, 1998] quando ainda estava na escola, mas nomear esse espectáculo é ingrato porque há dezenas de outros que teria de nomear a par desse, tão e mais importantes. Como também foi de uma importância vital a primeira vez que fui ao Espaço de Tempo. Foi num espectáculo da Rafaela Santos, eu não queria acreditar que um espaço daqueles era possível em Portugal. O Espaço do Tempo foi uma grande revolução na minha vida, por tudo aquilo que estar ali potencia. Como também foi muito importante toda a experiência da Capital enquanto espectador, ainda me recordo dos horários, às quartas, pelas 19h, era dia de leituras. Um dia, será conhecida de todos a história daquele lugar e do que aquelas pessoas ali fizeram. Talvez então saibamos explicar aquele tornado que foi a Capital, e quem sabe, fazer qualquer coisa com isso. Bem como a Revista dos Artistas Unidos, e depois os Livrinhos de Teatro da Cotovia. Como também foi importante ter vivido fora, em Nova Iorque, como também tudo o que vivi, o desporto que fiz...

\section{Estudaste no Lee Strasberg Theatre Institute, em Nova Iorque, não foi?}

Não tanto por ter feito o curso do Lee Strasberg, mas mais por ter estado um ano em Nova Iorque, logo a seguir ao 11 de Setembro [2001], com vinte e um anos, e sozinho. Longe do meu país, com tudo o que isso implica. 


\section{Mas colocas-te enquanto espectador, como aprendiz?}

Acabamos sempre por ter uma fraca cultura geral sobre teatro ao vivo, se a compararmos com uma cultura sobre literatura ou cinema. Podemos tentar ver vídeos dos espectáculos, ou ler as peças quando é o caso, podemos ver as fotografias e os trailers, ler as críticas, podemos aproximar-nos, andar ali à volta, mas nunca é a mesma coisa. Por isso, todo o teatro que pudermos ver ao vivo será sempre pouco. A escola do espectador é das mais importantes, é da crítica que nasce muita da criação. Sempre me deixou muito intrigado o encenador que não vai ao teatro, se calhar também há escritores que não lêem ou realizadores que não vêem filmes.

\section{Olhando para o teu percurso, há um momento também muito particular que é o espectáculo Enquanto vivermos, na Culturgest, em 2012, um dos exemplos mais cristalizados daquilo que é uma experimentação do teatro ou um projecto experimental. Foi uma criação partilhada com o Romeu Costa em que a ideia era que o espectáculo pudesse durar enquanto vivessem, não é? Não volta- ram ao espectáculo?}

Não, não. Ainda não. Filmámos o ensaio geral do espectáculo e depois o espectáculo brincava com o documento do ensaio geral. No fundo, é um espectáculo que consiste nisso: na nossa relação com o documento do ensaio geral - 4 de Julho de 2012 - e que, portanto, está gravado e não voltámos lá ainda porque talvez não tenha passado tempo suficiente, deve ser isso. Mas, por falar em experimentação, eu acho que tudo o que fiz até hoje são ensaios. Ensaios para qualquer coisa que há-de vir.

Pensando na Mona Lisa, no Às vezes as luzes apagam-se, no Homem-Legenda, eram espectáculos com um formato mais estabilizado. A gramática de apresentação do espectáculo estava mais estabilizada.

Pode ser uma coisa de aparência, também. Eu, na segunda coisa que fiz, o Execução Pública, chamei-lhe «esboço para um espectáculo», que eu depois ainda iria fazer a seguir mas que nunca cheguei a fazer. E o Tiago Bartolomeu Costa escreveu uma crítica em que questionava isso mesmo. Questionava-se: se há um ensaio, como é que está tudo tão fechado aparentemente? Mas para mim não estava, um ensaio pode ter luzes e 


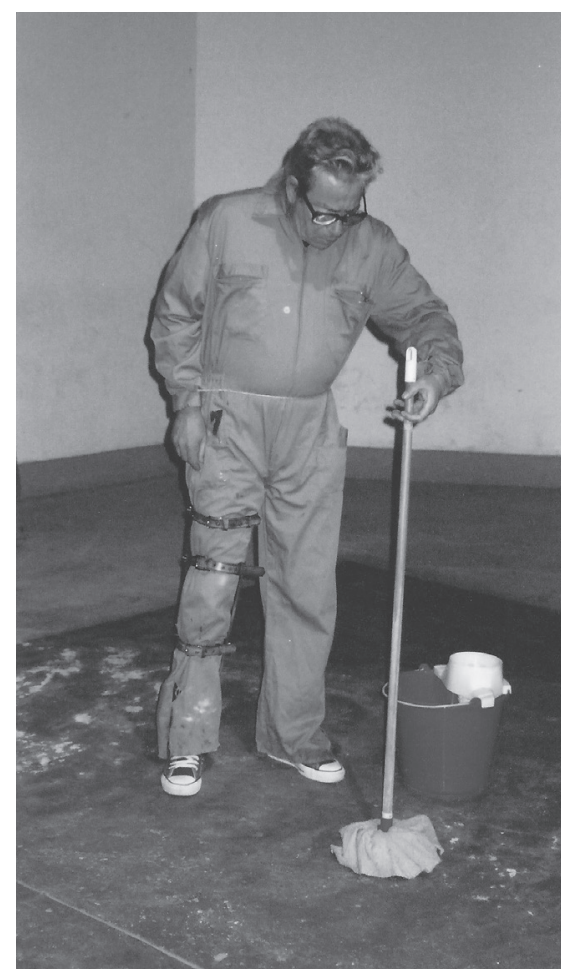

EXECUÇÃO PÚBLICA, DE PEDRO GIL, 2005, BARBA AZUL (HORÁCIO MANUEL), [F] JOSÉ FRANCISCO AZEVEDO

cenografia e figurinos e ainda assim ser um ensaio, um rascunho. No fundo, aquilo ou continuaria, ou eu teria de amarfanhar as coisas e deitá-las fora como acabei por fazer e desembocar numa outra coisa, que aparentemente não tem nada que ver com a anterior, mas é sua consequência.

Queria fazer uma provocação. Poderias fazer toda a vida o Execução Pública?

Sim, sim, mas não o continuei a fazer porque não era por ali.

OK. Foi o ensaio de um caminho, então?

É, porque no fundo um espectáculo pode transformar-se num outro.

Vou ver o que é que há aqui e aqui e aqui.

E não só. No fundo a procura é a mesma, os objectos é que são diferentes. A pesquisa é cumulativa e é difícil, às vezes, identificar em quê. Mas ela é cumulativa ao mesmo tempo que se transforma. Como a vida, estamos 


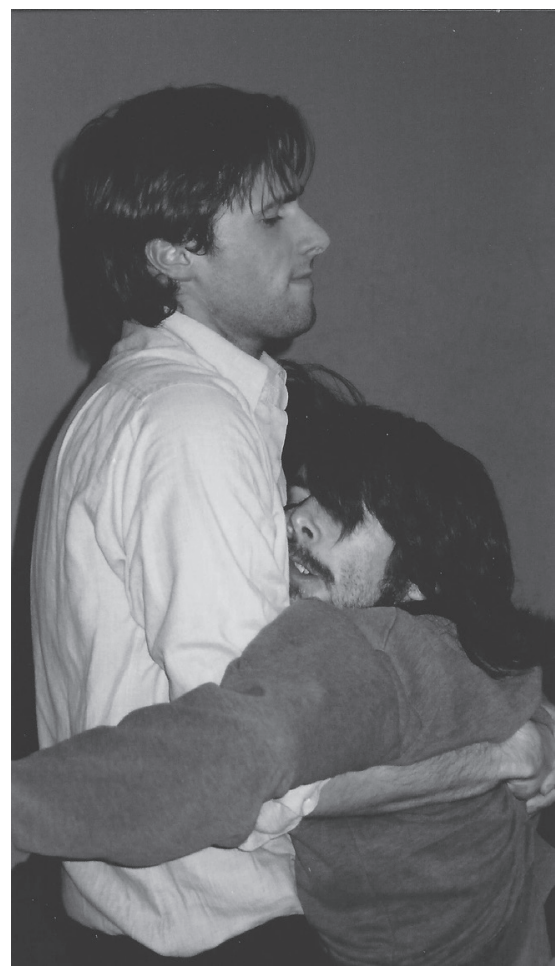

sempre a somar e a transformar. Isto pode parecer que estamos sempre a falar do mesmo e que a forma é que é diferente, mas o interessante é que a própria forma transforma aquilo sobre o qual estamos a falar. $\mathrm{E}$ com o tempo, quer seja o tempo da vida de uma pessoa, quer seja o tempo da humidade, vivemos coisas novas e essas coisas novas darão naturalmente origem a formas novas. Esse trabalho para mim é infinito, suponho, até ao momento daquela que seria a realização máxima. Mas não sei, nunca me aconteceu.

A percepção de que falávamos há pouco, de que no Enquanto vivermos há uma espécie de novo capítulo ou outra gramática a tentar ser ensaiada ou outro caminho a tentar ser descoberto. É uma percepção nossa? Para ti, não? Não conheces esse momento como um momento para outra gramática?

Vem do mesmo lugar. O Homem-Legenda e a Mona Lisa são espectáculos mais semelhantes entre si, o Enquanto vivermos e o Don Juan são mais parecidos entre si. Mas ao mesmo tempo são tão diferentes, basta dizer que, no Enquanto Vivermos, o discurso directo era improvisado e que no 

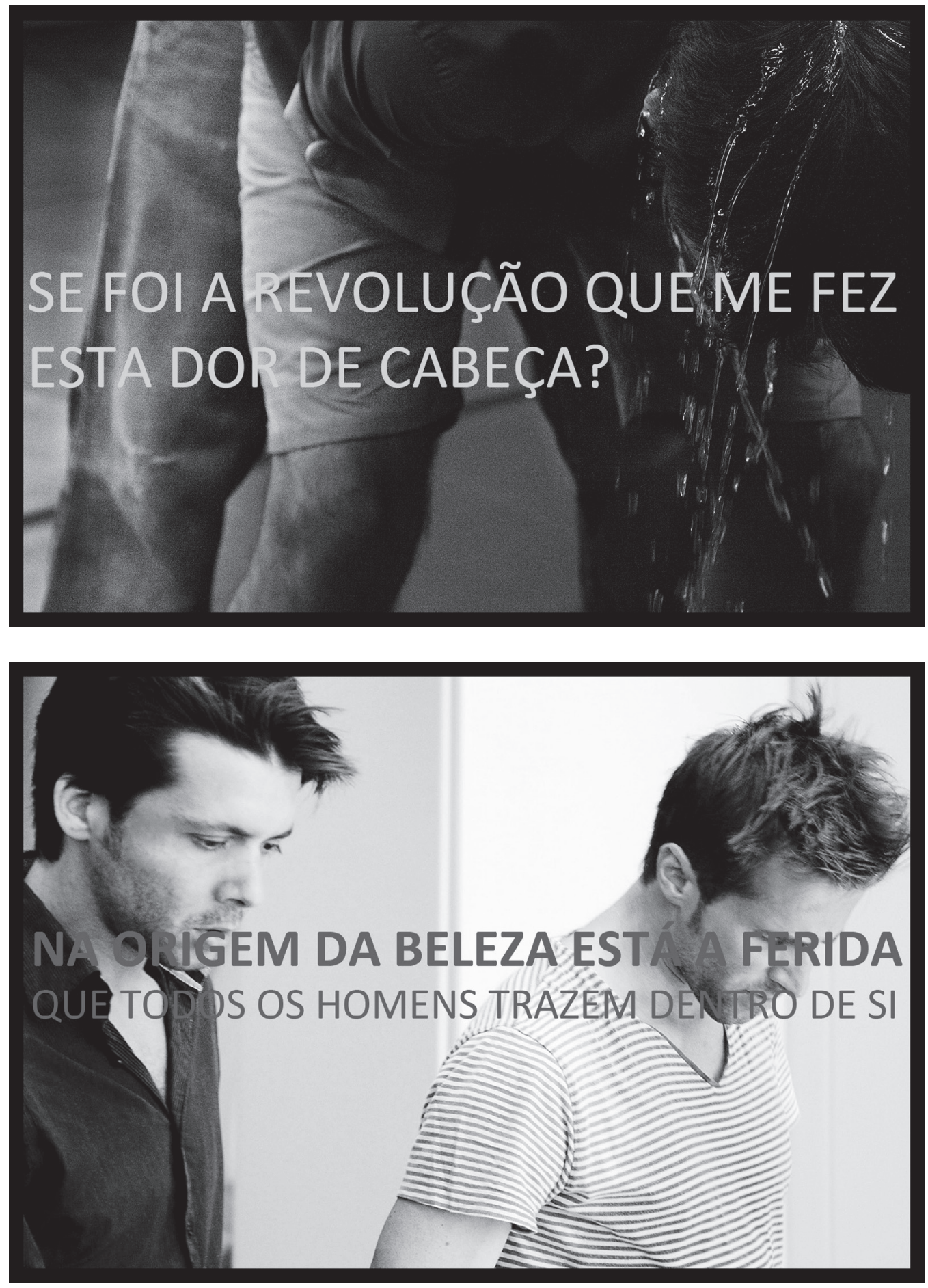

ENQUANTO VIVERMOS, DE PEDRO GIL, ANAPEREIRA.PEDROGIL (BARBA AZUL), 2012 (PEDRO GIL, ROMEU COSTA), [F] MARIANA C. SILVA 


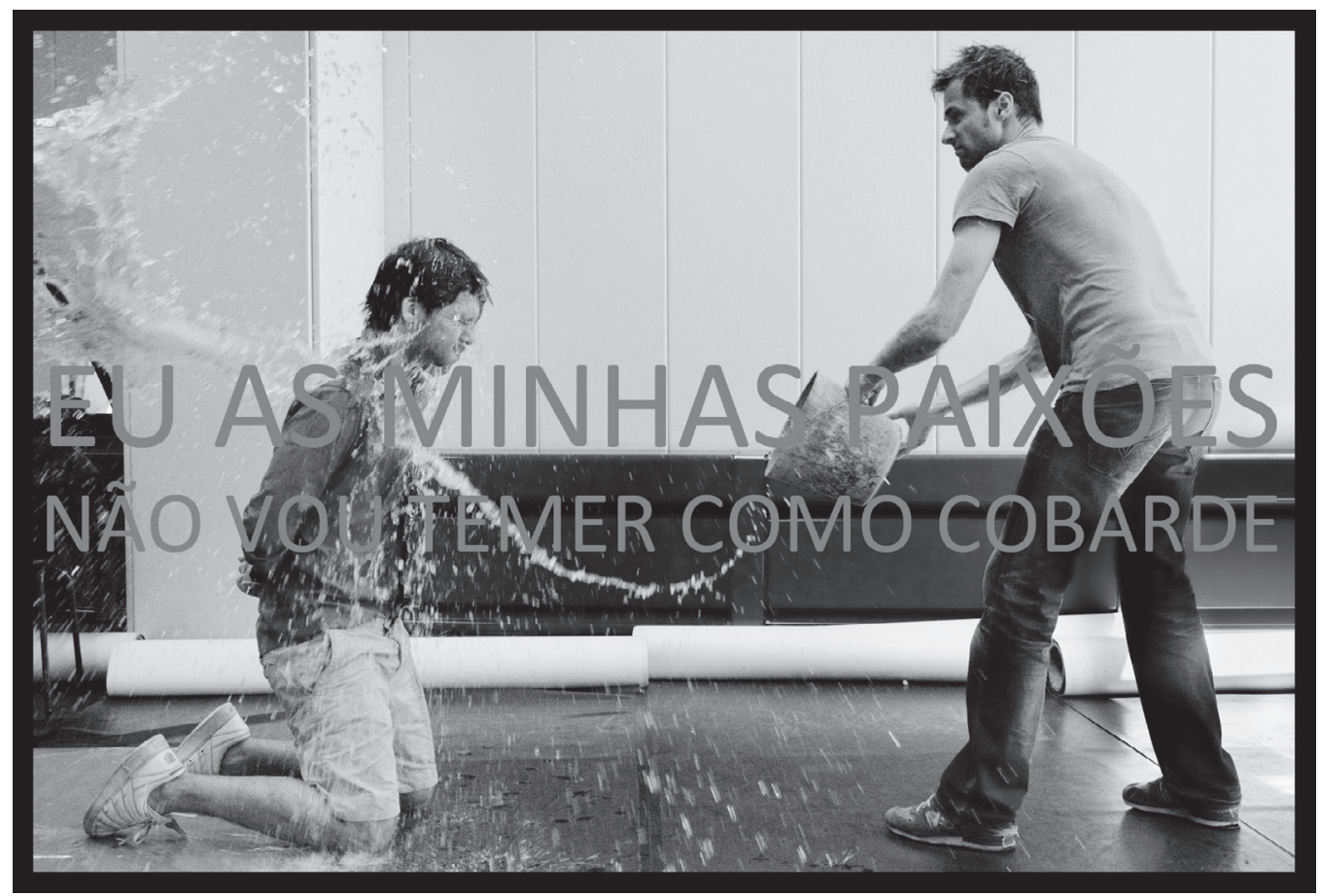

ENQUANTO VIVERMOS, DE PEDRO GIL, ANAPEREIRA.PEDROGIL (BARBA AZUL), 2012 (PEDRO GIL, ROMEU COSTA),

[F] MARIANA C. SILVA

Don Juan o texto foi escrito. Agora, pela forma como eu relaciono tudo dentro da minha cabeça, é a mesma procura. A pesquisa é a mesma, é o mesmo sentido, só vai ganhando novas formas.

E já estás em condições de partilhar que busca é essa e que sentido é esse que procuras?

Não sei se consigo...

Há um refrão muito visível que é uma espécie de pulsão confessional. Espectáculos onde o confronto é muito feito «olhos nos olhos», para a frente. Formalmente, há uma busca por uma espécie de simplicidade, também muito visível no Don Juan, com o despojamento cenográfico. Há ali uma espécie de herança do Jacques Copeau ou do espaço vazio do Brook... Um despojamento cénico e um centralizar na paleta expressiva do actor, não é? $\mathrm{E}$ depois em termos temáticos há uma irrupção da sordidez na vida quotidiana que aparece sempre. 


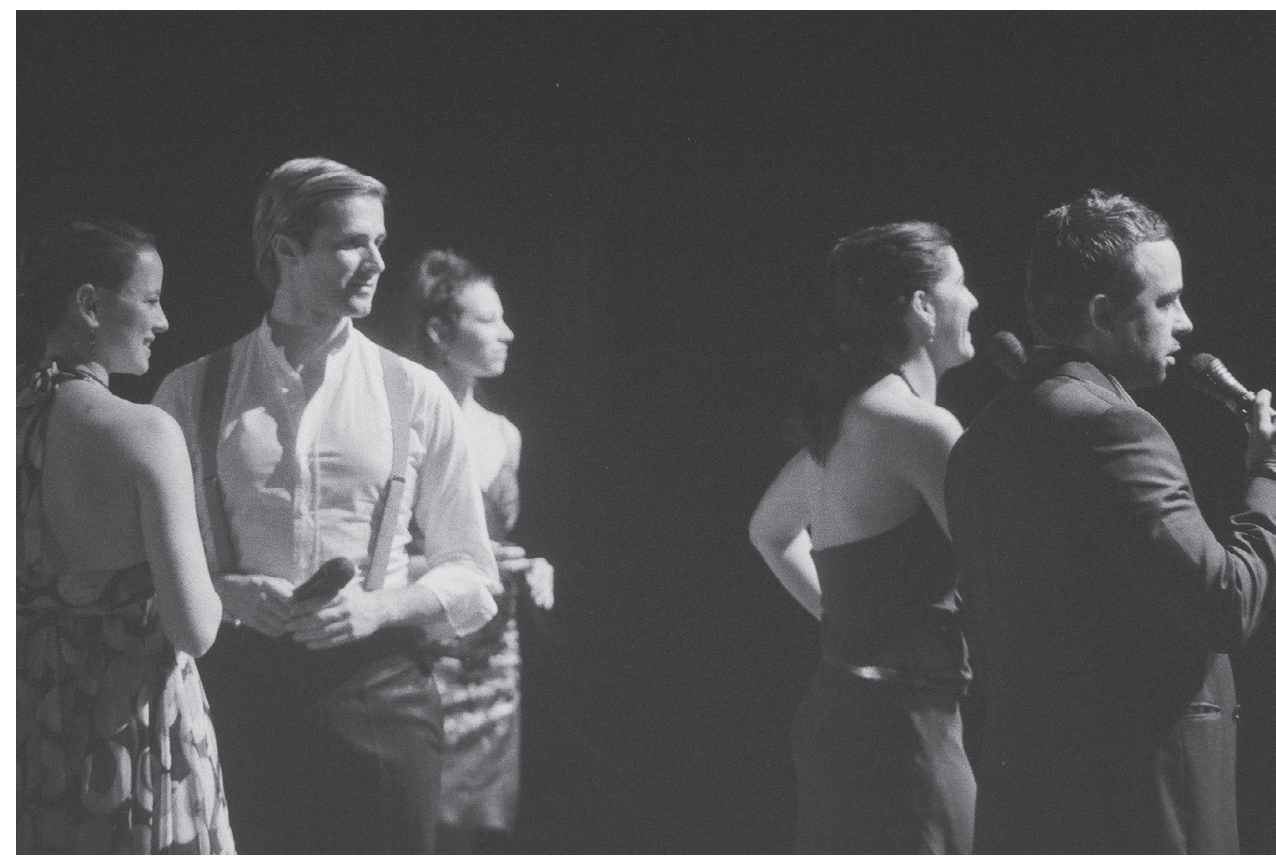

MONA LISA SHOW, DE PEDRO GIL, 2008, BARBA AZUL (RAQUEL CASTRO, ROMEU COSTA, AINHOA VIDAL, MÓNICA GARNEL, RICARDO GAGEIRO), [F] JOSÉ FRANCISCO AZEVEDO

As coisas mais abjectas dentro de um quotidiano. Vemos isso no Mona Lisa, mais timidamente, e muito substantivamente no Enquanto vivermos; e muito no Don Juan. Como se por baixo de uma banalidade do quotidiano estivesse latente uma pulsão vital mais sórdida, mais urgente, mais bruta, mais primata.

O foco, a perspectiva, é sobre as relações humanas, a natureza humana. São as camadas da natureza humana. Se estivéssemos a fazer pergunta ao contrário, se nos perguntasses a nós o que achávamos que era a tua busca, a resposta era esta: encontrar ali reflexos, cromatismos, camadas da natureza humana, que tu experimentas como actor e que também vês e que tu sentes. E isso é uma coisa que reconhecemos desde o Homem-Legenda - sentes claramente necessidade de falar sobre elas.

Eu acho que há um primeiro momento em que somos espectadores e sentimos qualquer coisa quando vemos aquilo acontecer diante de nós. Há essa experiência primordial do espectador, não é? Que nos faz sentir: «Eu acho que quero ir para ali, quero estar ali em cima, quero fazer aquilo.» 


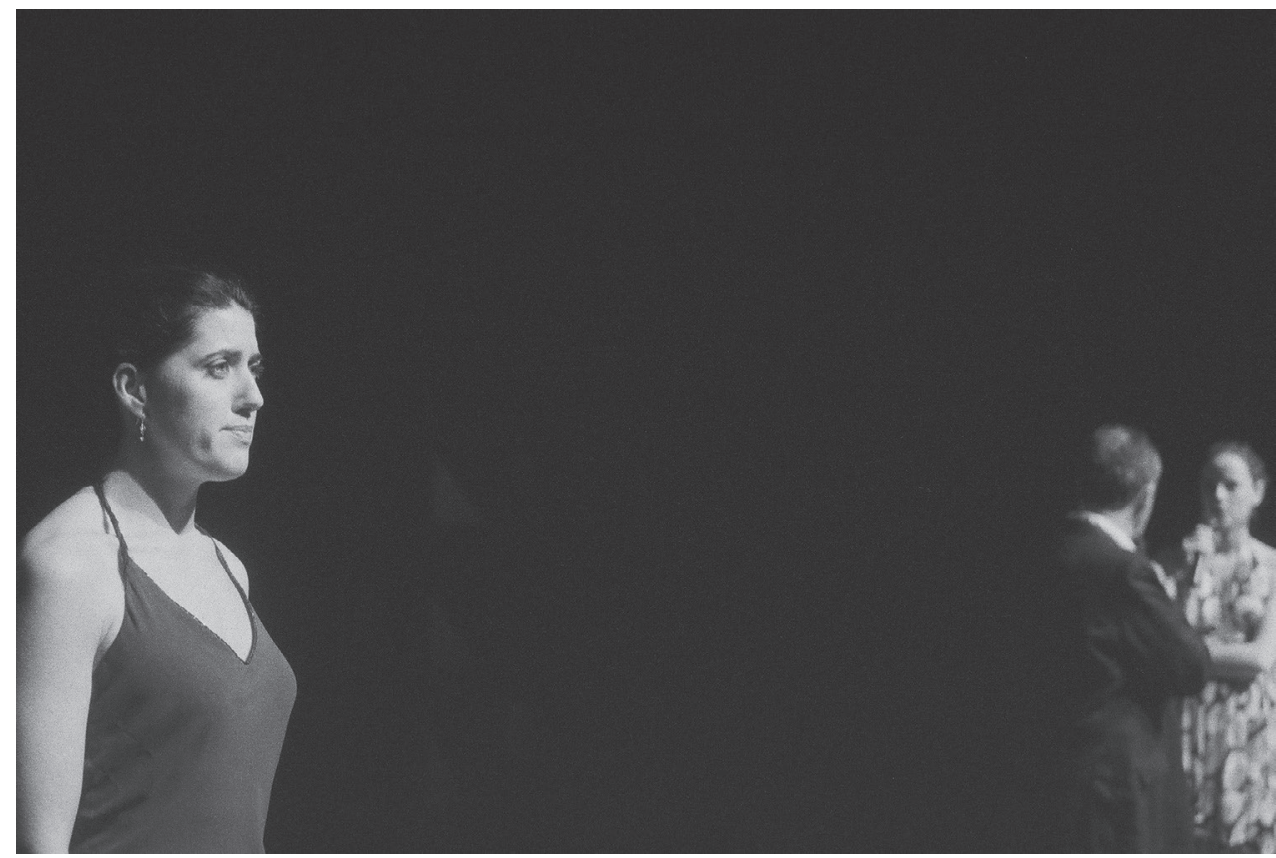

MONA LISA SHOW, DE PEDRO GIL, 2008, BARBA AZUL (MÓNICA GARNEL, ANTÓNIO FONSECA, RAQUEL CASTRO), [F] JOSÉ FRANCISCO AZEVEDO

E depois passamos o resto da vida a tentar reviver essa sensação, mas desta vez em cima do palco, a tentar proporcionar essa sensação nos outros. E o caminho para aí chegar creio que passa sempre por perguntar o que é que o teatro pode ser, para mim. Porque é que eu senti aquilo daquela vez, porque é que fui naquele dia ao teatro, do que é que eu estava à espera, porque é que aquilo me tocou?

Atrai-me o teatro como forma de celebração e como forma de gozo, no sentido em que a vida parece pedir para ser satirizada e celebrada ao mesmo tempo. Porque tudo é ridículo e tudo é belo, a cada momento e ao mesmo tempo. É a sua comédia. A vida não faz sentido e ao mesmo tempo é maravilhosa. $\mathrm{E}$ o estarmos ali também. $\mathrm{O}$ acto teatral para mim toca-me muito nesse sentido. $\mathrm{E}$ depois continuo a gostar que me contem histórias. E mais, o facto de alguém poder representar essa história à minha frente é incrível.

O teatro pode ser feito de mil e uma maneiras, mas sem dúvida nenhuma que ficamos todos a perder quando o teatro se demite da representação. Já sabemos que uma rosa em cena é uma rosa, sabemos que não temos de estar sempre a comparar o mundo do palco com o nosso mundo. 
Há muitas formas de uma coisa me tocar sem ser pela identificação. E a responsabilidade dessa possibilidade tem de ser partilhada entre todos, por todos os criadores do espectáculo, bem como pelo espectador. Uma rosa em cena pode mesmo ser só uma rosa e isso ser tocante. É do domínio da arte conseguir fazer isso, encontrar a sua própria poesia. Mas por isso mesmo uma rosa em cena também pode ser outra coisa, e isso não tem mal. Não tem mal encontrarmos nela o nosso mundo ou outros mundos. Abdicar dessa possibilidade simbólica de representação, abdicar da interpretação, é um tiro no pé. Com tudo aquilo que essa possibilidade arrasta: narrativa, personagens, mimese, composição, interpretação, identificação, ilusão, etc. As coisas além daquilo que são podem parecer outras coisas, isso acontece em arte, é um facto, não há que ter medo dele. A questão é como. Representar no sentido mais lato é uma actividade humana ancestral. Por vezes, é mágico e misterioso e escuro, e não há nada de errado nisso, quando um actor diz umas palavras que o fazem parecer outro, que o fazem parecer estar a viver uma realidade que extravasa a realidade do palco, por momentos. Mas só na nossa cabeça, porque ele continua a ser o mesmo, apenas está a dizer aquelas palavras daquela maneira. Querer à força impedir esse fenómeno de acontecer não só é impossível, como é tonto, como ainda por cima, talvez tenha sido por isso que todos viemos aqui parar.

Independentemente do meu domínio ser a forma, a questão de fundo, claro, é como é que eu me consigo realizar, e para tal eu acabarei sempre por fazer qualquer coisa, em primeiro lugar que seja capaz, e em segundo lugar, qualquer coisa que me toque a mim como fazedor e como primeiro espectador, ainda que faccioso, do que faço. $\mathrm{O}$ sentido que eu procuro para viver vai contaminar a arte que estou a fazer, é a mesma vida, a minha. Se conto determinadas histórias, ou crio determinadas personagens, ou passo por determinados temas, isso é porque teve de ser.

\section{Então, se entendemos, de forma mais grosseira, uma coisa que não buscas é um teatro auto-reflexivo, um teatro que se demita do diá- logo com o mundo e que se feche sobre si próprio.}

Eu acho que não sei o que é um teatro que se feche sobre si próprio. Eu acho que o teatro, a partir do momento em que é uma actividade pública, nunca se fecha sobre si próprio, por mais que o artista possa querer, o público não o permitirá, chama-se interpretação e esta é livre. Mesmo o teatro que fala sobre teatro fala do mundo, porque o teatro faz parte do mundo, até o mundo do teatro. Não sei se percebo a pergunta. 
Para mim, tem mais que ver com criar um mundo novo, cénico, com a consciência de que esse mundo poderá sempre ser comparado com o mundo real do espectador, sendo que o mais engraçado e libertador é que eu nunca saberei o que é o espectador.

O tema do Don Juan, por exemplo, era a mentira, não é? Há ali uma grande diferença entre a primeira parte e a segunda parte do espectáculo. A primeira parte parece-me mais fiel ao original, ao passo que a segunda parte está mais perto de uma reescrita da peça. Queres falar um bocadinho sobre isso a propósito destas questões sórdidas sobre a natureza humana?

Por um lado, creio que nós continuamos a achar, como pessoas que fazem teatro, que a maior parte das pessoas estabelece relações entre aquilo que lê num texto antigo e o presente. Isso nem sempre acontece. Mesmo que nós tenhamos os actores com calças de ganga e tenhamos pistolas em vez de espadas, a chamada «actualização» pode não se dar. Nós, como primeiros leitores daquele texto, achamos que sim, pensamos: «Como é que isto foi escrito há quinhentos anos? Vou já pôr isto em cena para as pessoas perceberem o que se passa com a vida delas.» A verdade é que não precisa de ser assim, não temos de pegar em textos antigos para mostrar como eles são actuais. Eles podem valer por si enquanto coisa longínqua ou muito simplesmente enquanto matéria. Quis brincar com algumas destas coisas. Como é costume dizermos que encenar um clássico é trazê-lo até nós, foi o que fiz, literalmente. Peguei nele e fi-lo viajar literalmente no tempo, mas ele permanece como era apesar de ser catapultado para o futuro. A primeira parte do Don Juan tem tanto de actualidade como, para mim, a segunda parte, e ambas já são passado, já são datadas. Mas no fundo o que me atrai é aquilo que é transversal aos dois tempos, é mais o que os une do que aquilo que os separa. Depois, a maneira como a cena se materializa tem que ver com ela, com as suas próprias leis internas, aí entramos de novo no domínio da forma. Eu lanço as sementes e depois, aos meus olhos parece surgir um universo que se rege por si. No início, tudo é possível e depois vai deixando de ser, como de resto, na vida. Se não gostar do resultado, já sei que o melhor é ir semear para outro lado. O trabalho só termina quando a cena vibra, como uma corda de uma guitarra afinada, é assim e não assado, mas não sei explicar melhor isto, parece-me ser mais subjectivo do que afinar uma guitarra. Para mim encontrar isso, essa afinação, é o meu grande 


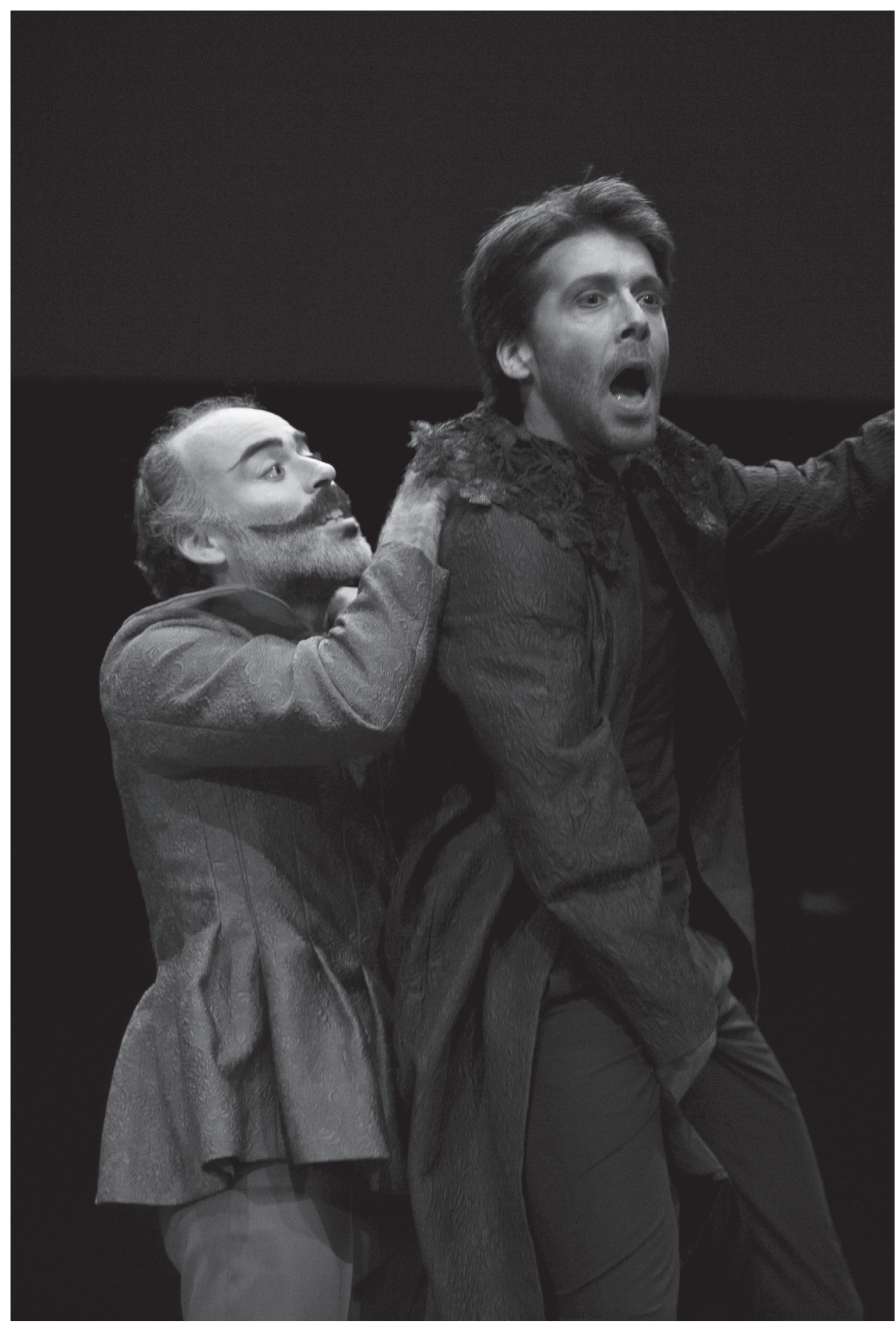

DON JUAN ESFAQUEAdO NA AVENIDA DA LIBERDADE, DE PEDRO GIL, 2018, BARBA AZUL (PEDRO GIL, TÓNAN QUITO), [F] MARIANA C. SILVA 

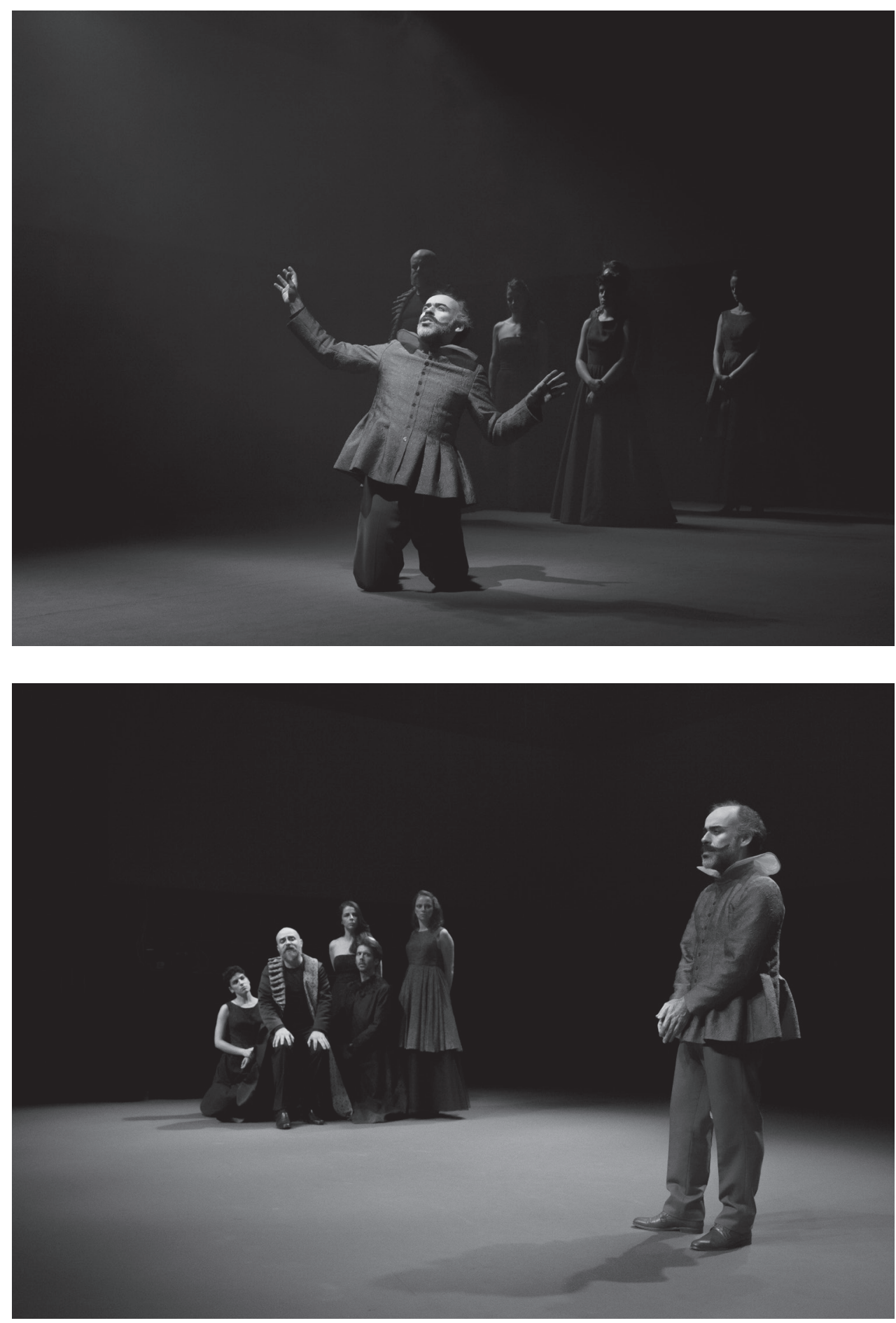

DON JUAN ESFAQUEADO NA AVENIDA DA LIBERDADE, DE PEDRO GIL, 2018, BARBA AZUL (TÓNAN QUITO, MIGUEL LOUREIRO, RITA CALÇADA BASTOS, PEDRO GIL, FILIPA MATTA, RAQUEL CASTRO, [F] MARIANA C. SILVA 
prazer e gozo. É fazer aquela cena vibrar de forma a me tocar. «Tocar» aqui pode significar muitas coisas. O Tolstói, na fase final da sua vida, diria que é fazer-me sentir qualquer coisa. $O$ que é que perguntaste em relação ao Don Juan?

\section{Qual era diferença para ti entre a primeira parte e a segunda parte?}

A primeira parte brinca com coisas do cânone, passa-se no século XVII e tem algumas cenas com ingredientes que são recorrências de muitos Don Juans, e a segunda parte passa-se no século XXI; para mim, a diferença é só essa. Tanto a primeira parte como a segunda são escritas tendo a personagem do Don Juan como ponto de partida. Não é uma colagem de citações, nem reescrita de texto. Tanto quanto sei, há apenas duas citações propositadas ao longo de toda a peça. A personagem é que arrasta consigo um determinado conjunto de situações associadas ao cânone; nesses casos aproveitámos a situação, eu e os actores, mas criámo-la do zero; depois, existem outras situações que já não pertencem ao cânone e que são possibilitadas pela fuga dele para Lisboa e pelo salto no tempo. O Don Juan é uma personagem que me toca muito, é de infinitas possibilidades, é só pôr o Don Juan em qualquer contexto e esperar que aconteça alguma coisa. Ele é um vírus narrativo. Coisas que me tocam na relação com o feminino, na relação com o trabalho, na relação com a fé, na relação com a família, na relação com o dinheiro, com o outro, com a morte, com a paternidade, com o poder, a pátria... O Don Juan, para mim, é tudo isso e muito mais.

Na forma como lemos o espectáculo, a figura do Don Juan surge como uma espécie de comentário depreciativo em relação à natureza humana hoje. Há no Don Juan um certo olhar romântico sobre a vida. Na primeira parte do espectáculo, seguimos esse olhar. Mas depois, essa figura, é posta num tempo onde o mais banal dos mortais é mil vezes pior que Don Juan. Vimos o espectáculo como uma espécie de comentário autodepreciativo sobre os nossos modos de vida. Os nossos modos de vida, assentes justamente nessa questão da mentira. Na mentira que se cola ao espectáculo, o espectáculo como construção.

A mentira é um dispositivo que está presente durante a peça toda porque ele muitas vezes tem de mentir para fugir, para se safar, para seduzir, 
para conseguir o que quer e, claro, faz ao mesmo tempo parte do teatro, pertence ao seu território, por mais que a tentemos banir. Nunca mais me hei-de esquecer do meu Avô a garantir-me que o corte que eu fazia, com um bisturi, ao Romeu Costa no Esboço do Miguel Loureiro, era mentira. E o Romeu ali a esvair-se em sangue... Aquilo que me dá mais graça é ser um vilão a pôr o dedo na ferida, alguém que não tem legitimidade moral para o fazer e nem sequer o faz com esse intuito. É uma óptima personagem para formular perguntas. Se é isso que sentiste, então é isso que é para ti. É claro que, sendo a minha aproximação ao teatro predominantemente dramática, o sumo acaba sempre por vir das contradições em que nós próprios nos pomos, e a maior parte delas são sociais. É natural que aquilo que faça nasça da tragédia humana, mas o desafio, julgo, é tornar esse drama, essa sátira social ou crítica de costumes, um objecto artístico de fruição estética, o que quer que isso seja, uma coisa que só seja pertença da arte, algo que só ela seja capaz de fazer. As pessoas fascinam-me como são, a sua tragédia é provavelmente a sua maior beleza, talvez aquilo que faço se aproxime mais do elogio. Mesmo que seja um elogio que fere. Por mais que eu queira ou não salvar-nos, somos o que sempre fomos e o mais provável é continuarmos assim. O poder do teatro, a sua função na sociedade, a sua utilidade, a sua inscrição na História vão sempre transbordar em muito as minhas intenções.

O próprio espectáculo também é uma mentira. É uma sucessão ou uma série de camadas de mentiras. A questão da sedução, que nós temos por determinante na história do Don Juan e que está consequentemente ligado ao amor, portanto, o Don Juan como aquele que é incapaz de amar porque é apenas capaz de seduzir e não de estar em continuidade com uma mesma pessoa, é de certa forma um bocadinho abafada para realçar esse lado da sedução como mentira, como estratégia, como estratagema. É uma opção?

O meu interesse em pegar no Don Juan como figura que já existe reside não tanto nele, mas mais naquilo que ele pode provocar nos outros. Ele é um vento que passa e atrás de si deixa um rasto de devastação.

A companhia Barba Azul é a tua estrutura de produção há já muitos anos. Entretanto, foste-te assumindo cada vez mais como autor, encenador, criador... 


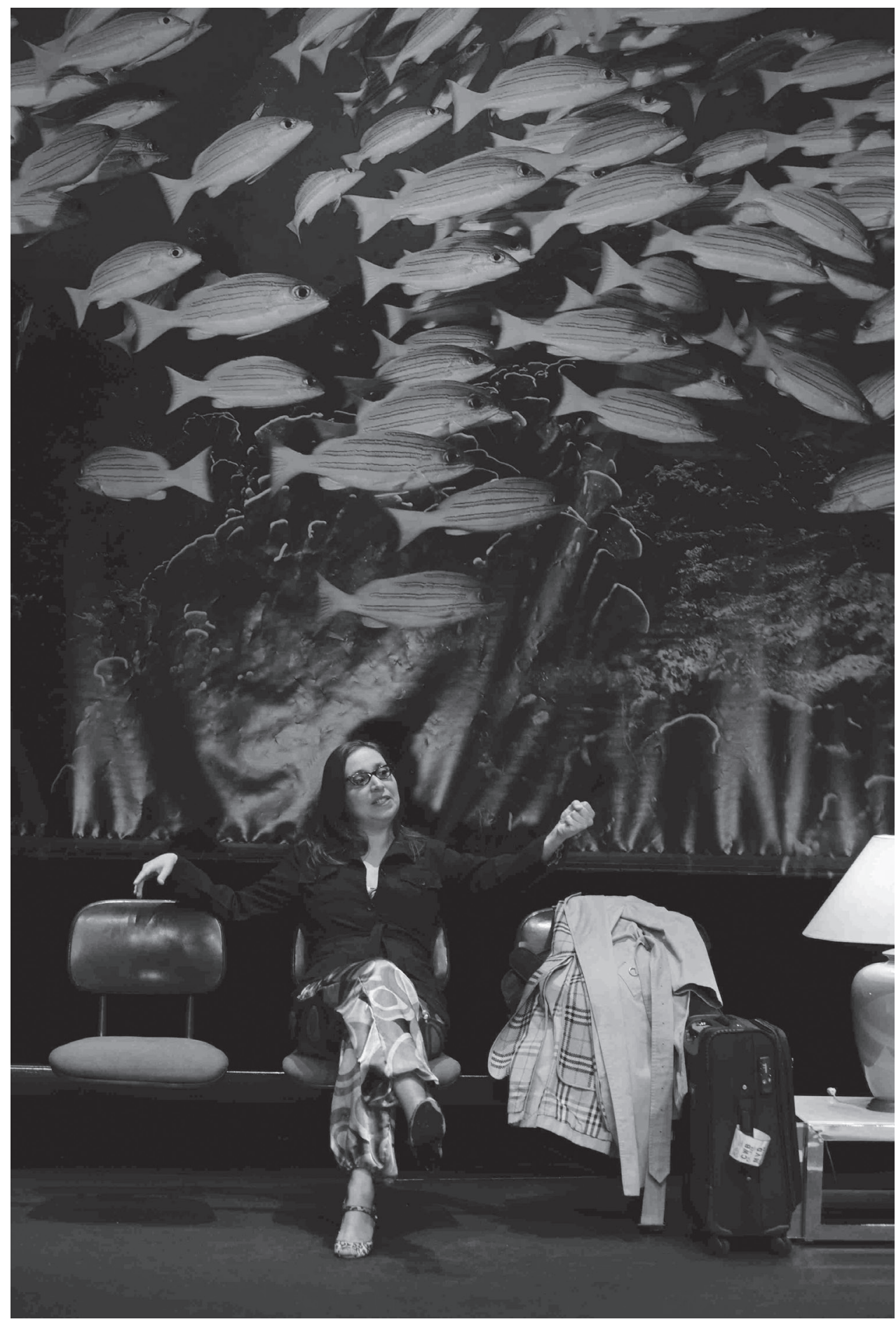

SALA VIP, DE JORGE SILVA MELO, ENC. PEDRO GIL, 2013, ARTISTAS UNIDOS E BARBA AZUL (ANDREIA BENTO), [F] JORGE GONÇALVES 
Fundei a Barba Azul em 2004 com a Ana Pereira, que saiu em 2012. Actualmente, partilho a direcção com a Raquel Castro e a produção é do Vitor Alves Brotas. Um dos nossos desafios enquanto companhia, no futuro, será por um lado tentar fazer teatro para outras pessoas, literalmente, não fazer teatro sempre para as mesmas pessoas nos mesmos sítios. Por outro lado, usar o teatro de uma forma mais ampla. Nem sempre o teatro como ferramenta é usado em todo o seu espectro de possibilidades. Outro desafio será o de trabalhar em continuidade e em profundidade. Quando falo em continuidade, falo também de trabalhar com as mesmas pessoas por maiores períodos de tempo. E, claro, ter um espaço.

Nós cometemos um erro grave, no meio de tanta coisa fantástica que fizemos: fomo-nos demitindo de ter um espaço. Pensámos que seria melhor uma estrutura de produção mais leve, trabalhar a partir de casa, só com um computador e uma impressora, o que em certa medida é verdade e pode ser o melhor modelo para muitos, mas não é para todos. Deixámos de sonhar com ter um teatro, com água para pagar, e luz, e segurança, e pessoas contratadas. Seria uma trabalheira, um problema, iríamos dissolver-nos ali. Às vezes há falhas no telhado e pinga no palco, é uma chatice. E nós o que queremos é ter tempo para criar e ler e escrever e ver filmes e ensaiar e pesquisar. Mais a ideia preconcebida que temos das companhias do passado, as relações viciadas, as pessoas que trabalham demasiados anos juntas, a estagnação, acomodam-se artisticamente, repetem-se, mais a figura do encenador-ditador. E sempre pensámos que o meu teatro não tem de ser só meu, qualquer teatro público é meu também. O problema é que não há teatros públicos suficientes para albergar toda a gente. Com receio disto tudo, decidimos ser «livres». Ora bem, essa liberdade paga-se depois, e caro: entre mim e o público, há sempre um intermediário. E não há nada de errado disso, muitos deles são pessoas fantásticas e fazem um trabalho fantástico, fui desafiado e apoiado por muitos. O que digo é que não tem de ser sempre assim. Eu nunca sou dono do tempo em que estou em cena, não tenho espaço para ensaiar, não tenho espaço para arrumar coisas, e não é preciso ser muito inteligente para perceber que isso perturba o trabalho. Mas acima de tudo, não tenho controlo sobre o tempo de exibição, e isso é para mim o maior problema do teatro actual. Sem tempo de exibição, suficiente, não há crítica, deixa de fazer sentido, não se cria memória na cidade, as coisas não deixam lastro, os artistas não evoluem no seu próprio trabalho, nem o público consegue estabelecer um diálogo com o artista. E se não é para a minha cidade que faço teatro em primeiro lugar, 


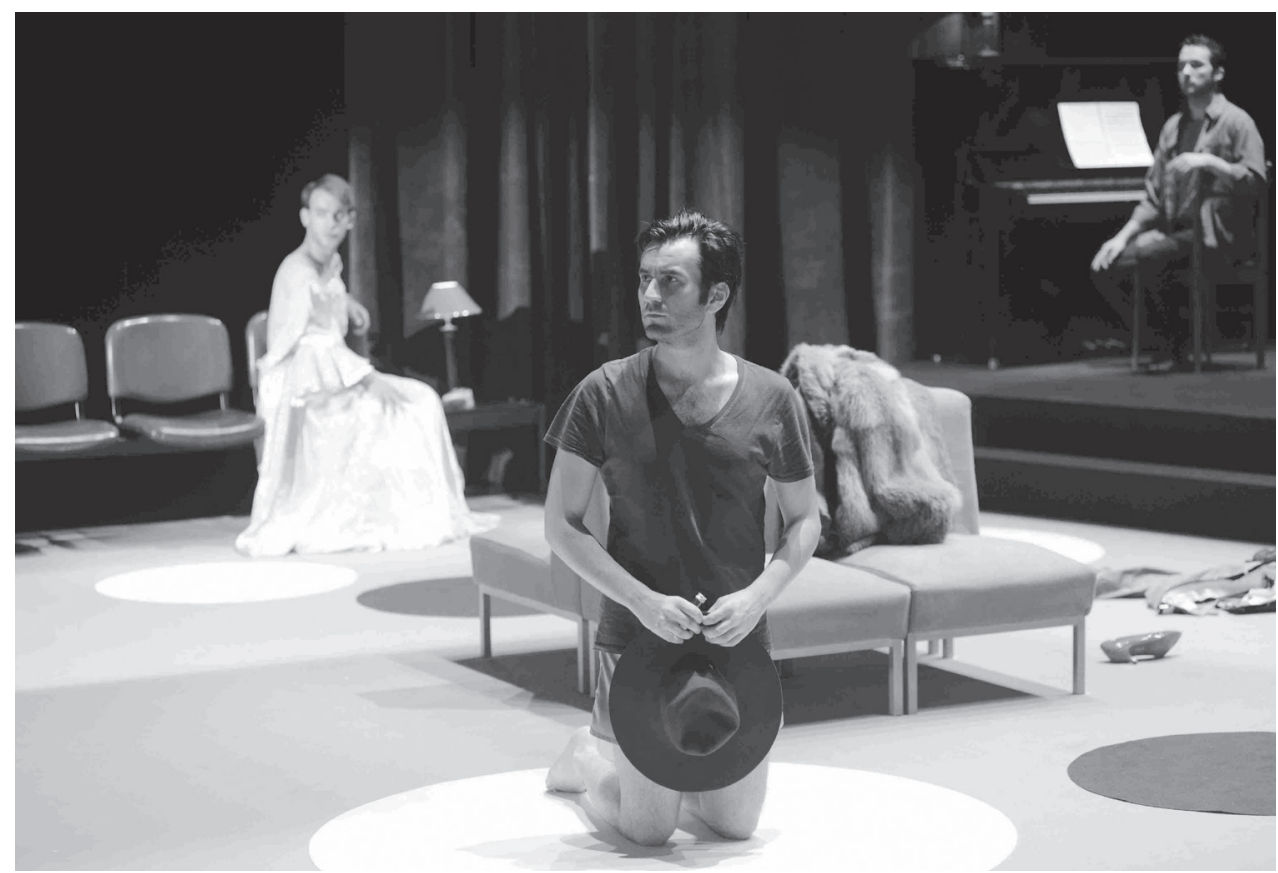

SALA VIP, DE JORGE SILVA MELO, ENC. PEDRO GIL, 2013, ARTISTAS UNIDOS E BARBA AZUL (JOÃO PEDRO MAMEDE, ELMANO SANCHO, JOÃO ABOIM), [F] JORGE GONÇALVES

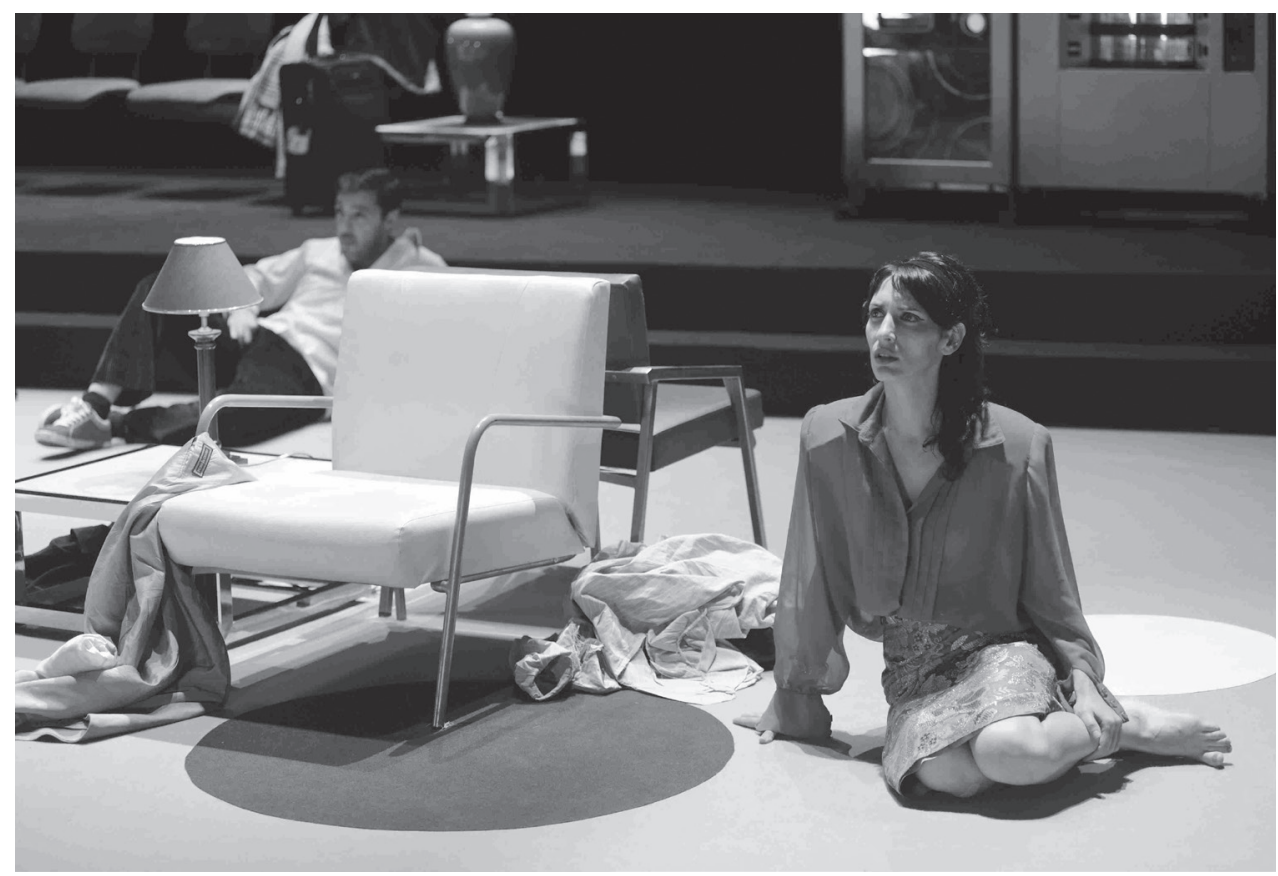

SALA VIP, DE JORGE SILVA MELO, ENC. PEDRO GIL, 2013, ARTISTAS UNIDOS E BARBA AZUL (MARIA JOÃO FALCÃO, ANTÓNIO SIMÃO), [F] JORGE GONÇALVES 
é para quem? O público não consegue criar uma relação afectiva com o teatro porque aquele espaço não é sinónimo de nada, não significa nada. É como ir àquele restaurante que tem aquelas pataniscas tão boas, mas que afinal hoje vende sushi e para a semana é uma marisqueira. Como é que eu crio um vínculo afectivo com um lugar destes? E esse é um problema que afecta o trabalho, «para é que vamos construir um cenário se é só quatro dias? Se calhar, mais vale não fazer. Se calhar nem vale a pena decorar o texto. Vamos pôr todos um auricular. São só quatro dias». Está a matar a classe artística também do ponto de vista financeiro, porque, se faço um espectáculo quatro dias, num fim-de-semana, na segunda-feira tenho de começar a ensaiar outro; é que eu ganho ao mês e não à récita. Em vez de estar um ou dois meses, ou o que for, a fazer um espectáculo e assim rentabilizar um património que tenho, que está fresco e que está pronto a usar, mas que quase sempre deitamos fora. Passo a vida a deitar fora coisas acabadas de nascer, que ainda não cresceram, que ainda não viveram o que podiam ter vivido. Se pensarmos bem, isso é de uma violência emocional incrível, mas o mais incrível é a gente habituar-se. Quando fazemos apenas quatro récitas, estamos sempre a fazer teatro para os mesmos, mas ganhamos na mesma os prémios e até ficamos contentes quando alguém nos diz: «Ó pá, adorava ter visto. Ouvi dizer muito bem.» $\mathrm{O}$ grande desafio do teatro é existir, pura e simplesmente. Uma coisa que já me prometi a mim mesmo é que por menos de vinte apresentações por espectáculo, não faço. À cabeça. Isso para mim é assunto fechado. $E$ vinte não é nada... Isto como encenador, chegará o dia em que vou conseguir fazer isso como actor. E claro, ocupar os lugares de poder e os teatros. Esse também é outro caminho. Mas a verdade é que são precisos mais espaços, porque, com os poucos espaços e com o pouco dinheiro que há, é óbvio que é preciso rodar muito. Os teatros que existem têm, na sua maioria, o mérito de ter servido de salva-vidas a muitos artistas e companhias, mas não chegam de jangada para todos e não podemos passar a vida a sobreviver. Não podemos passar a vida em Montemor-o-Novo, no Espaço do Tempo, onde, aí sim, existem condições para ensaiar. Lembro-me de estar a trabalhar com o Miguel Seabra, pouco depois de a sala do Meridional estar pronta, e de ele dizer: «Há um tipo de trabalho que só vou conseguir fazer aqui.» Eu acredito nisso. Estive lá um ano a trabalhar e é verdade. Há um trabalho que ele só consegue fazer ali. Ele tem espaço de ensaio permanente, e isso é incrível. Ninguém fala disto, mas as salas de ensaio onde a maioria do teatro português nasce são horríveis, entre rotatividade, falta de espaço, 


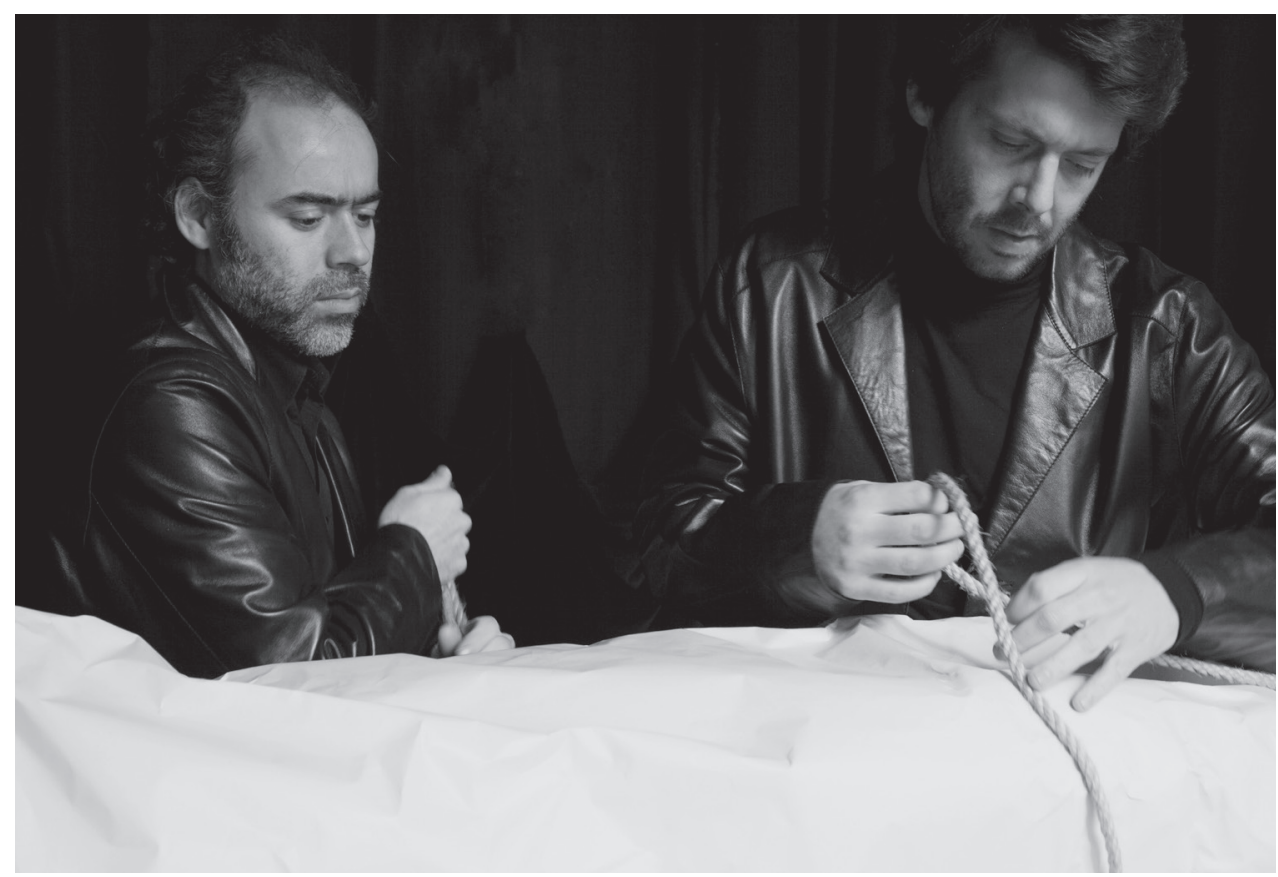

FAUSTA, A PARTIR DE O BANQUETE, DE PATRÍCIA PORTELA, ENC. PEDRO GIL E TÓNAN QUITO, 2014 (TÓNAN QUITO, PEDRO GIL), [F] MARIANA C. SILVA

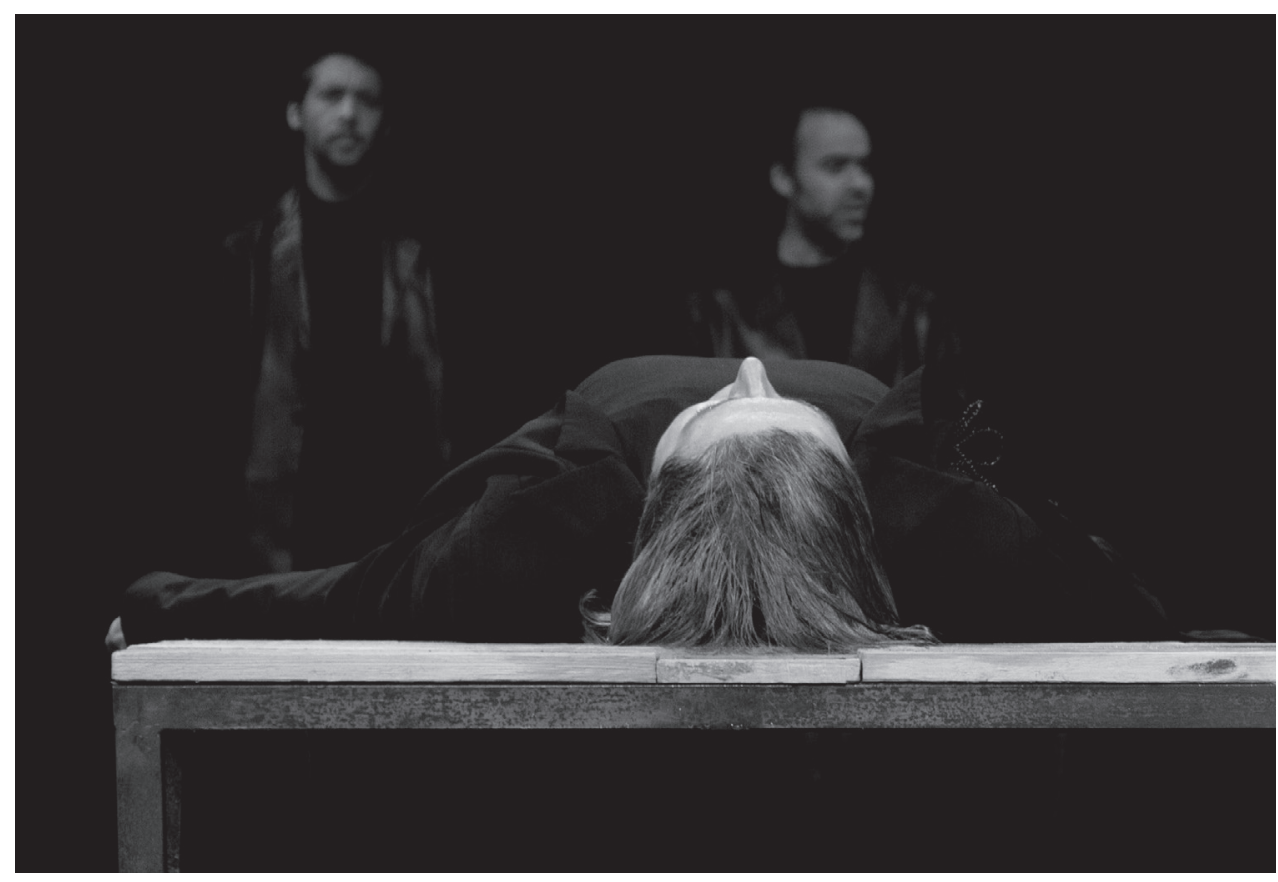

FAUSTA, A PARTIR DE O BANQUETE, DE PATRÍCIA PORTELA, ENC. PEDRO GIL E TÓNAN QUITO, 2014 (MARGARIDA ABRANCHES, PEDRO GIL, TÓNAN QUITO), [F] MARIANA C. SILVA 


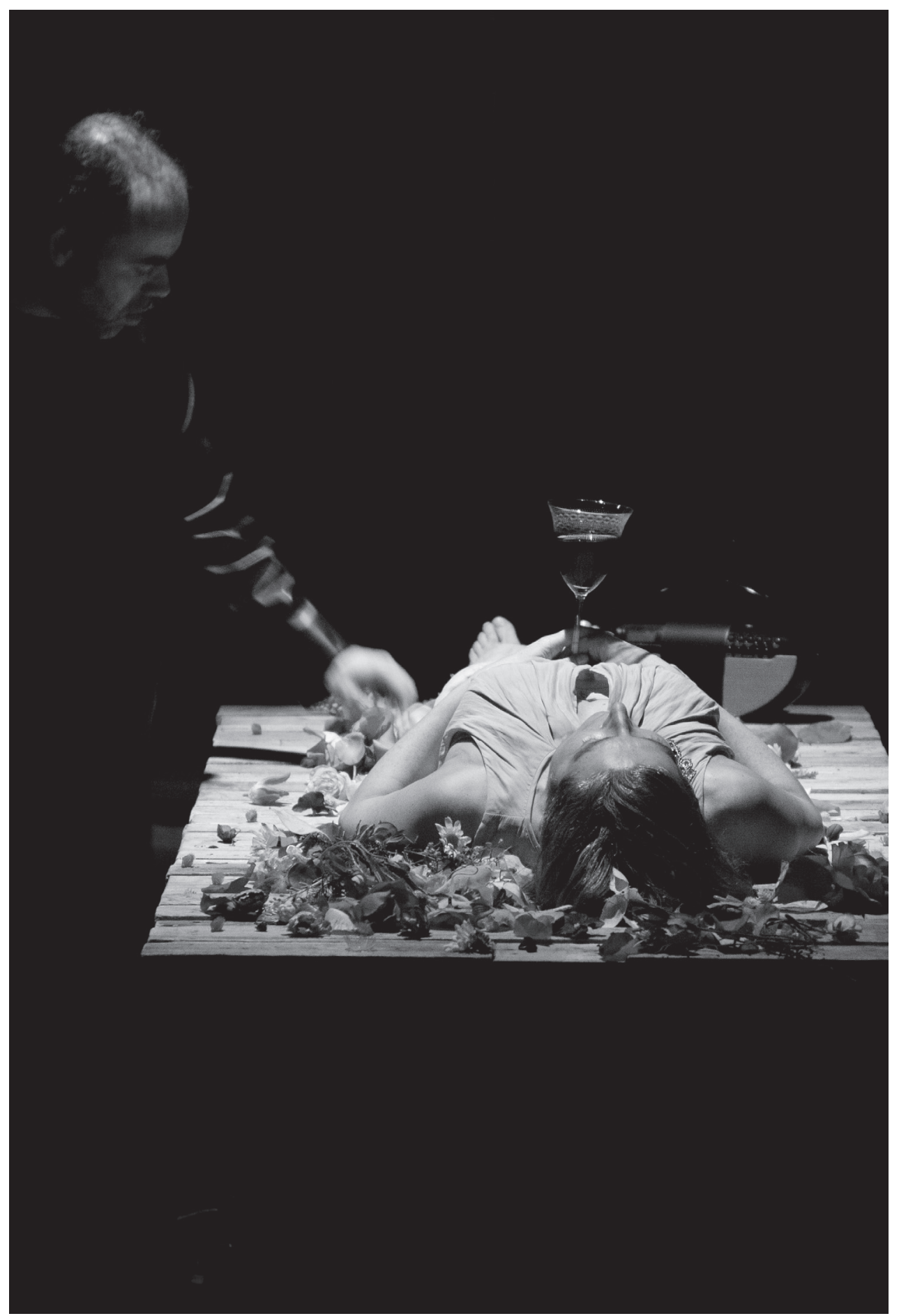

FAUSTA, A PARTIR DE O BANQUETE, DE PATRÍCIA PORTELA, ENC. PEDRO GIL E TÓNAN QUITO, 2014 (MARGARIDA ABRANCHES, TÓNAN QUITO), [F] MARIANA C. SILVA 


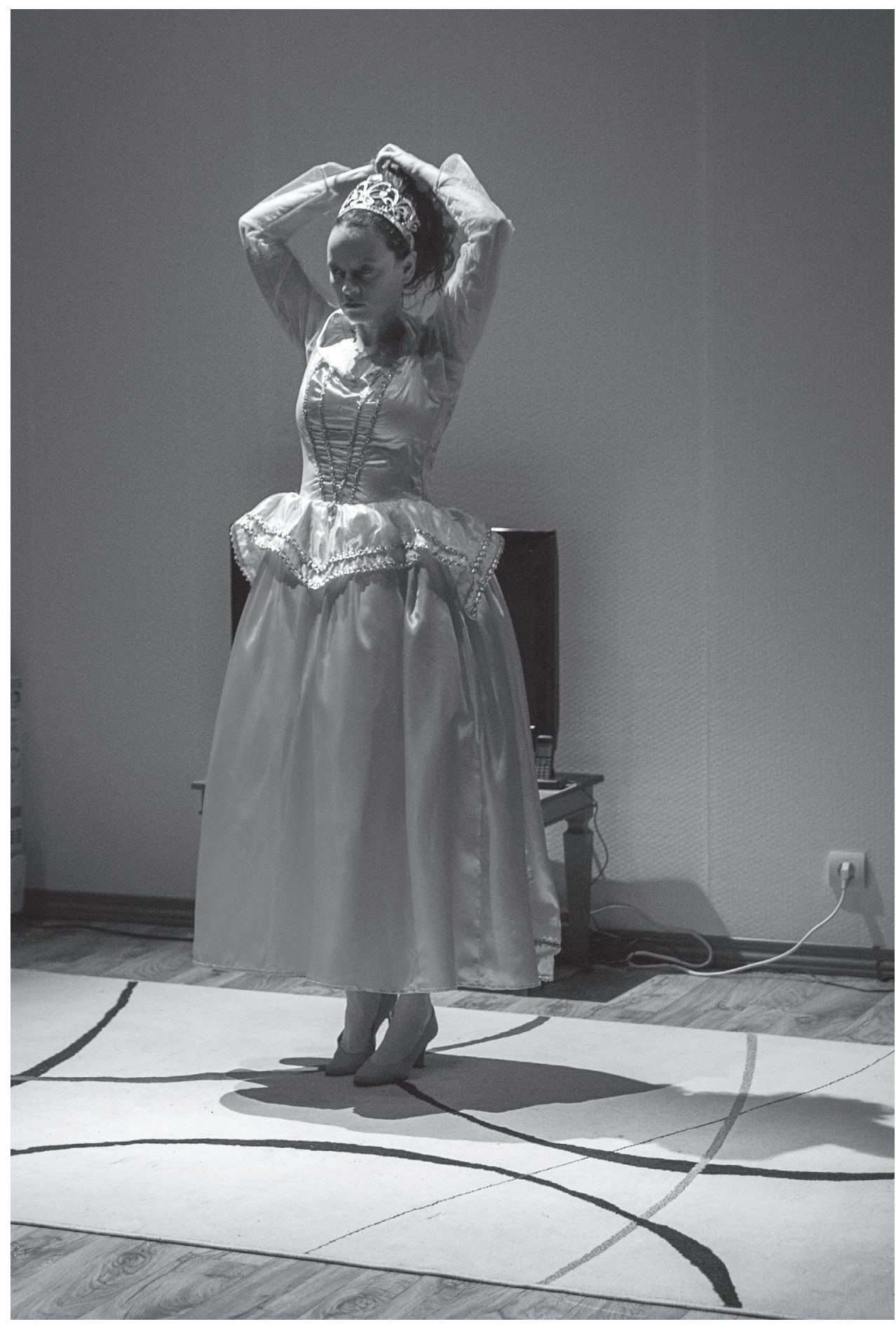

TERRENO SELVAGEM, CO-CRIAÇÃO PEDRO GIL, MIGUEL CASTRO CALDAS E RAQUEL CASTRO, TEXTO DE MIGUEL CASTRO CALDAS, 2016, BARBA AZUL (RAQUEL CASTRO), [F] MARIANA C. SILVA 


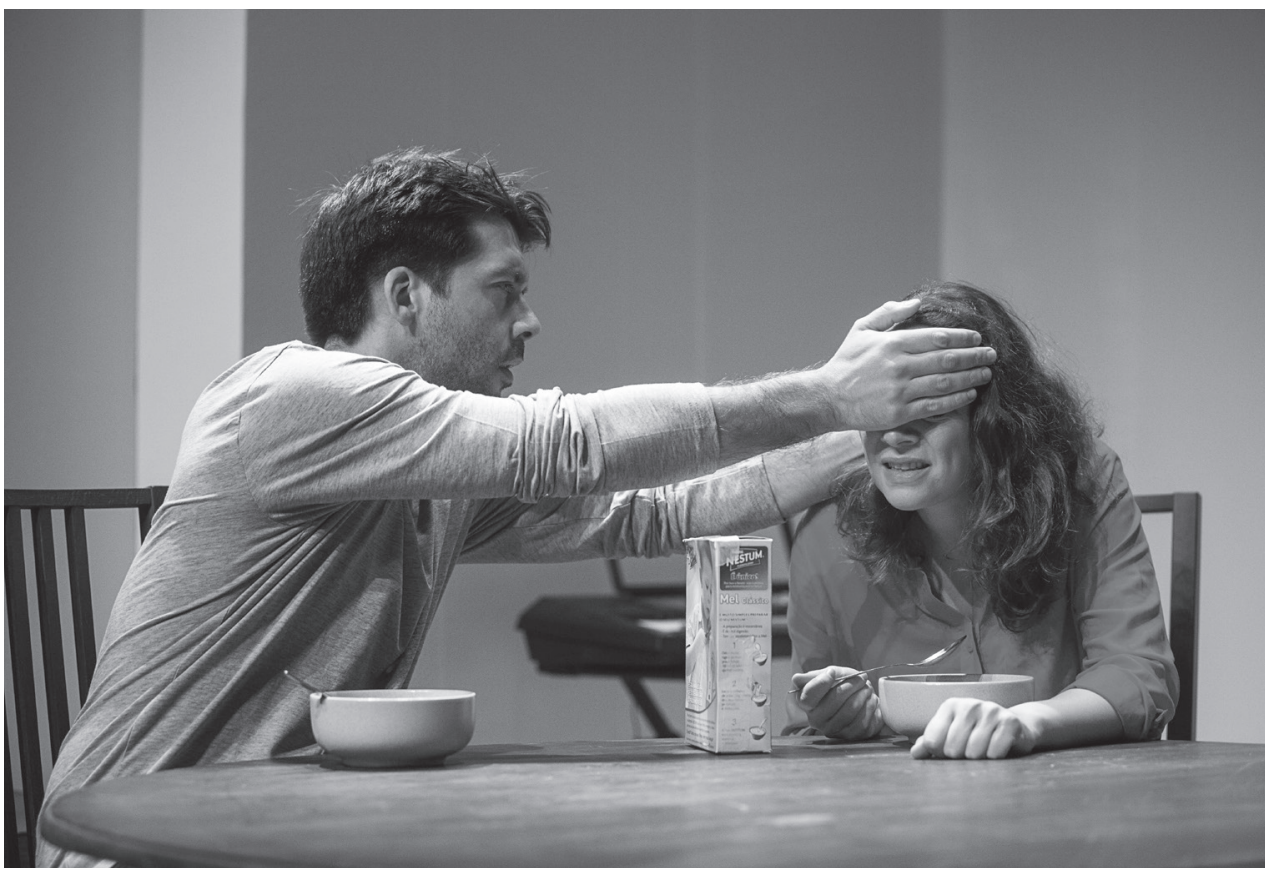

TERRENO SELVAGEM, CO-CRIAÇÃO PEDRO GIL, MIGUEL CASTRO CALDAS E RAQUEL CASTRO, TEXTO DE MIGUEL CASTRO CALDAS, 2016, BARBA AZUL (PEDRO GIL, RAQUEL CASTRO), [F] MARIANA C. SILVA

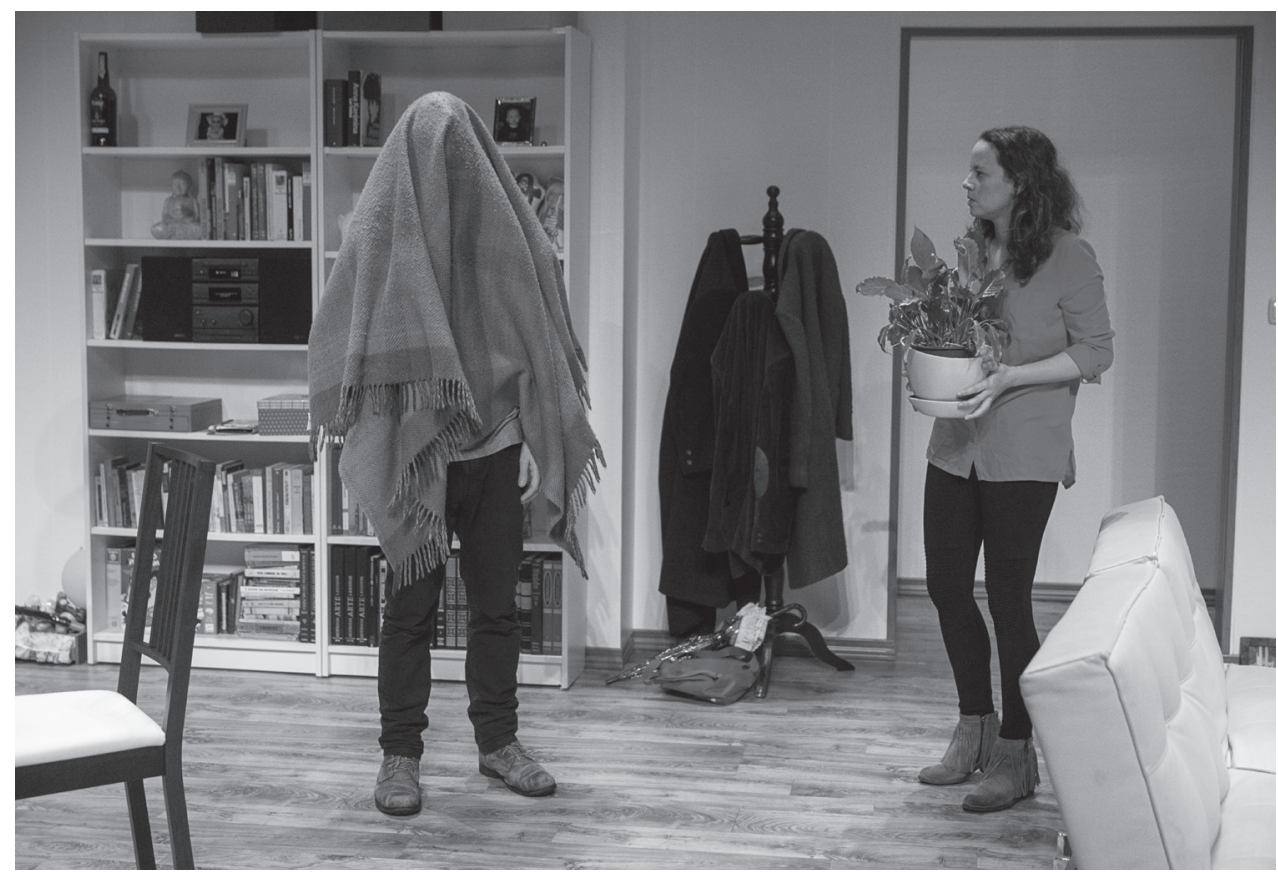

TERRENO SELVAGEM, CO-CRIAÇÃO PEDRO GIL, MIGUEL CASTRO CALDAS E RAQUEL CASTRO, TEXTO DE MIGUEL CASTRO CALDAS, 2016, BARBA AZUL (PEDRO GIL, RAQUEL CASTRO), [F] MARIANA C. SILVA 
falta de luz, frio e ácaros, venha o diabo e escolha. Em muitos sentidos, continuamos a fazer teatro profissional em condições amadoras. O Rui Horta só consegue fazer o trabalho que faz porque tem o espaço que tem, quartos com camas, duches, cozinhas, estúdios, escritório, lugar para guardar o material técnico. Os Artistas Unidos só conseguem fazer o trabalho que fazem porque têm uma Politécnica. Conseguem estar a ensaiar uma peça à tarde, estar a representar outra à noite, a expor artes plásticas na sala do lado, até conseguem vender livros na bilheteira. O Brites só consegue fazer o que faz, porque tem aquele espaço no Vale de Barris, até o tipo de trabalho cenográfico que ele faz inscrito na paisagem do vale e na arquitectura da própria quinta, até o trabalho com os actores. O teatro é uma coisa física que se passa no tempo e no espaço, precisa de infra-estrutura física. É como convidares alguém para ir jantar lá a tua casa, mas não teres casa para essa pessoa ir lá jantar. Como já disse, a casa não tem de ser tua, pode ser uma casa partilhada com vários encenadores, várias companhias, pode ser rotativo. Mas seja como for, são precisos mais teatros. Por isso aplaudo a Latoaria, o CAL, o Teatro Ibérico, o espaço do Teatro Praga, a mala voadora no Porto, são o recomeço de qualquer coisa.

Recuso-me a aceitar a ideia de que as companhias vão acabar, que no futuro nos vamos dirigir directamente aos teatros para pedir dinheiro e espaço para fazermos as nossas peças, recuso-me a aceitar que cada vez vamos ter menos tempo para ensaiar ou que cada vez estaremos menos tempo em cena. Quando estreei o Mona Lisa Show, estivemos quatro dias em cena no Centro Cultural de Belém (CCB) e tirei dinheiro da produção para irmos logo a seguir para o Meridional, onde fizemos mais duas ou três semanas. Visto que eu não podia estar no CCB mais de quatro dias e visto que eu não posso perder o dinheiro da co-produção, é a única forma de lutar contra isso. $\mathrm{O}$ que as pessoas parecem esquecer é que o dinheiro da criação tem de dar também para a exibição e que o dinheiro da exibição nunca fica para os artistas. É o mesmo dinheiro, ele não vem de outro sítio.

Disseste que é importante ocupar cargos de poder e obviamente a nossa geração está a tomar esse poder em variadíssimos casos, mas talvez também haja várias estratégias possíveis de relação com esse poder. Exigências tão simples como as vinte representações mínimas, como dizias há pouco, também são uma forma de resistência a essa imposição de que tudo tenha de ter quatro representações 


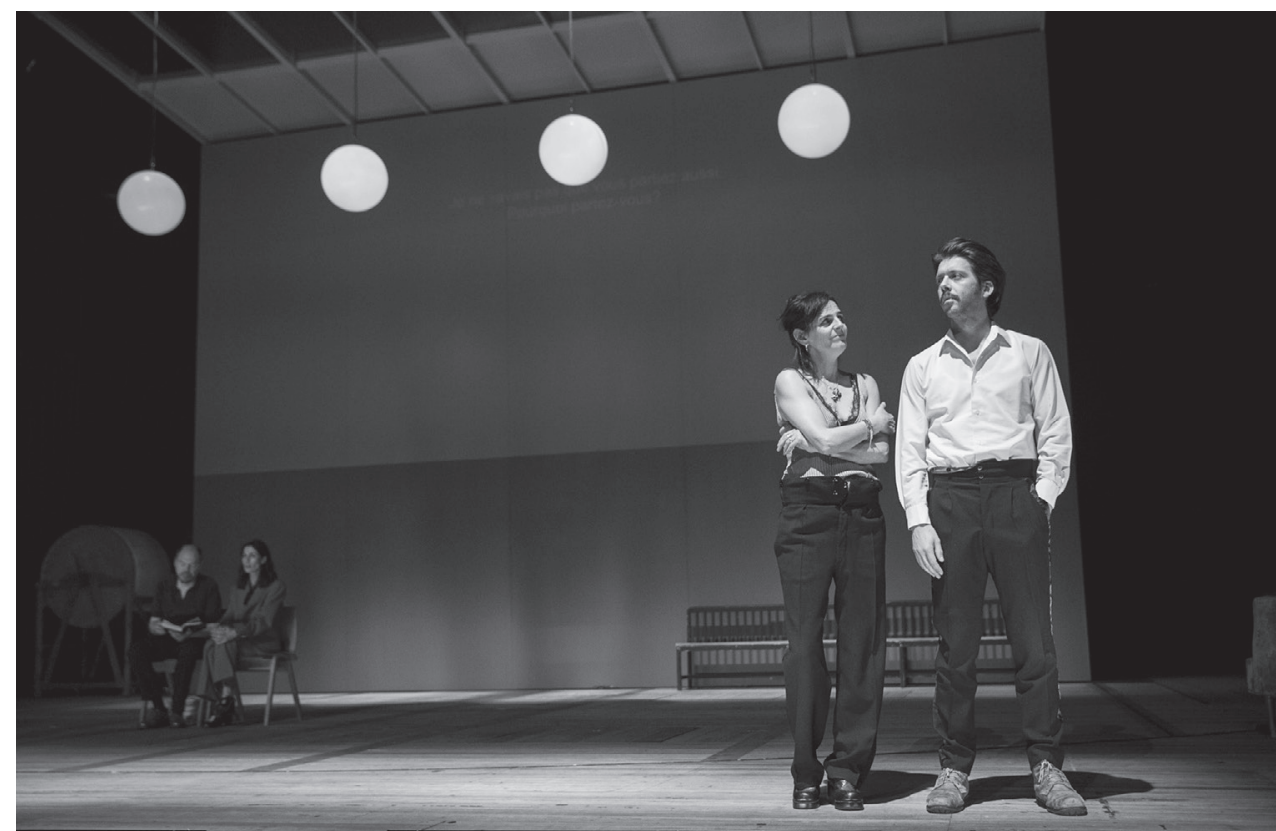

COMO ELA MORRE, DE TIAGO RODRIGUES, ENC. ISABEL ABREU, FRANK VERCRUYSSEN, JOLENTE DE KEERSMAEKER, PEDRO GIL E TIAGO RODRIGUES, 2017, TG STAN E TEATRO NACIONAL D. MARIA II (FRANK VERCRUYSSEN, ISABEL ABREU, JOLENTE DE KEERSMAEKER, PEDRO GIL), [F] FILIPE FERREIRA

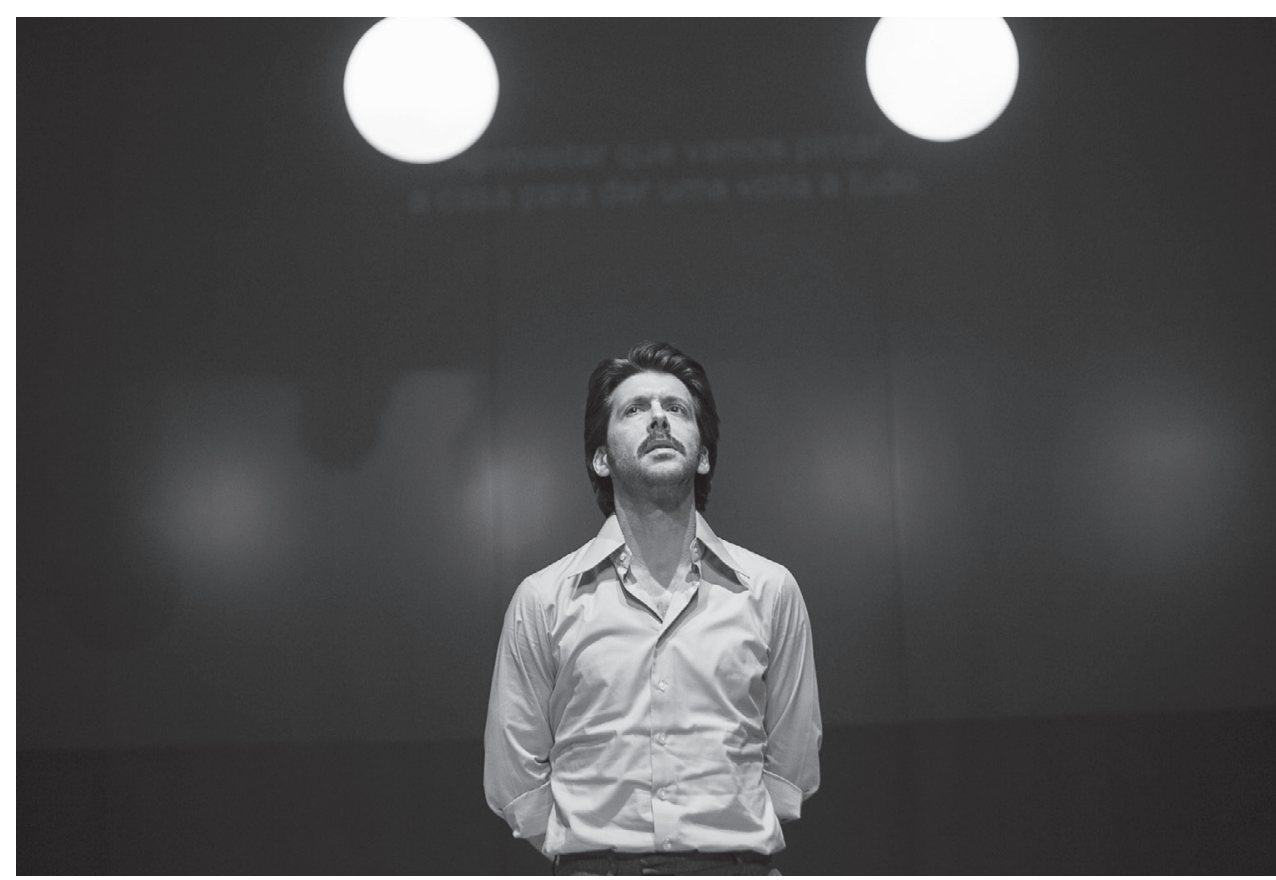

COMO ELA MORRE, DE TIAGO RODRIGUES, ENC. ISABEL ABREU, FRANK VERCRUYSSEN, JOLENTE DE KEERSMAEKER, PEDRO GIL E TIAGO RODRIGUES, 2017, TG STAN E TEATRO NACIONAL D. MARIA II (PEDRO GIL), [F] FILIPE FERREIRA 


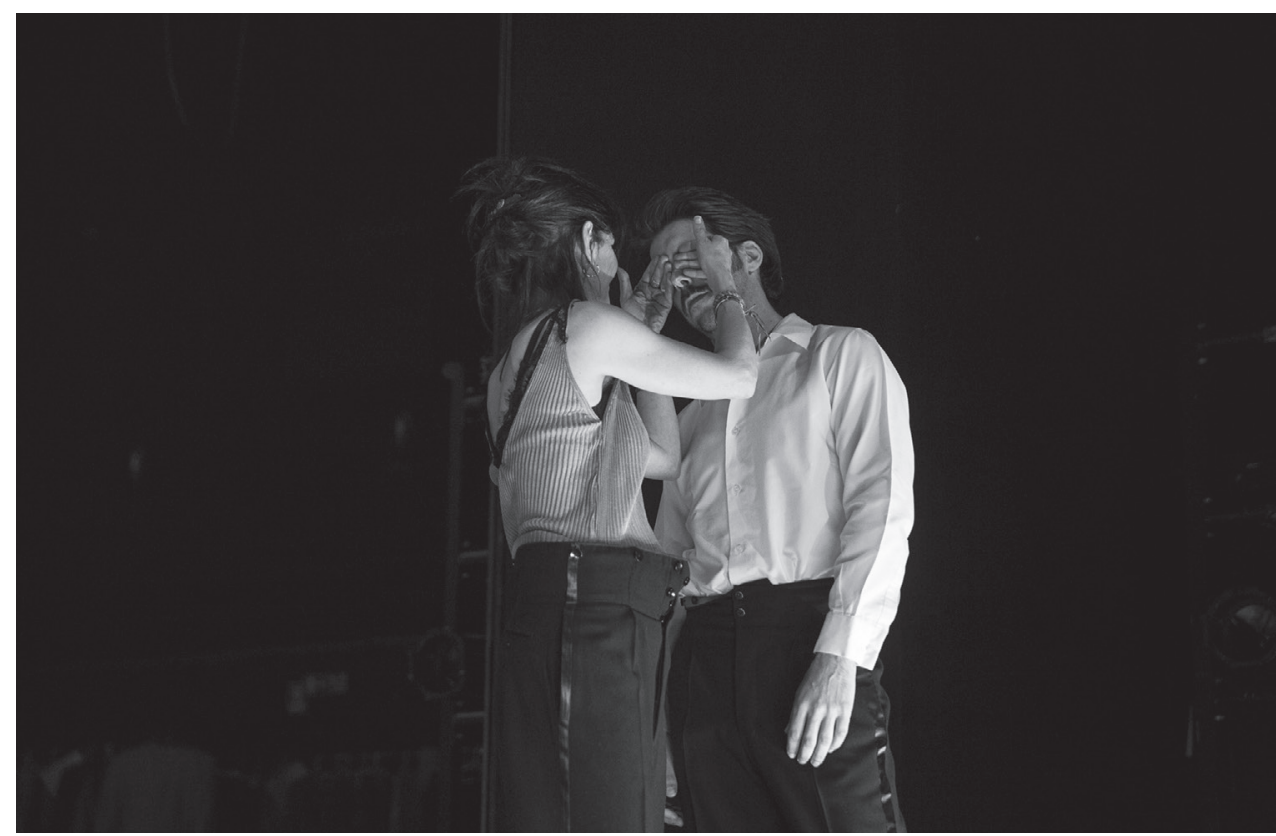

COMO ELA MORRE, DE TIAGO RODRIGUES, ENC. ISABEL ABREU, FRANK VERCRUYSSEN, JOLENTE DE KEERSMAEKER, PEDRO GIL E TIAGO RODRIGUES, 2017, TG STAN E TEATRO NACIONAL D. MARIA II (JOLENTE DE KEERSMAEKER, PEDRO GIL), [F] FILIPE FERREIRA

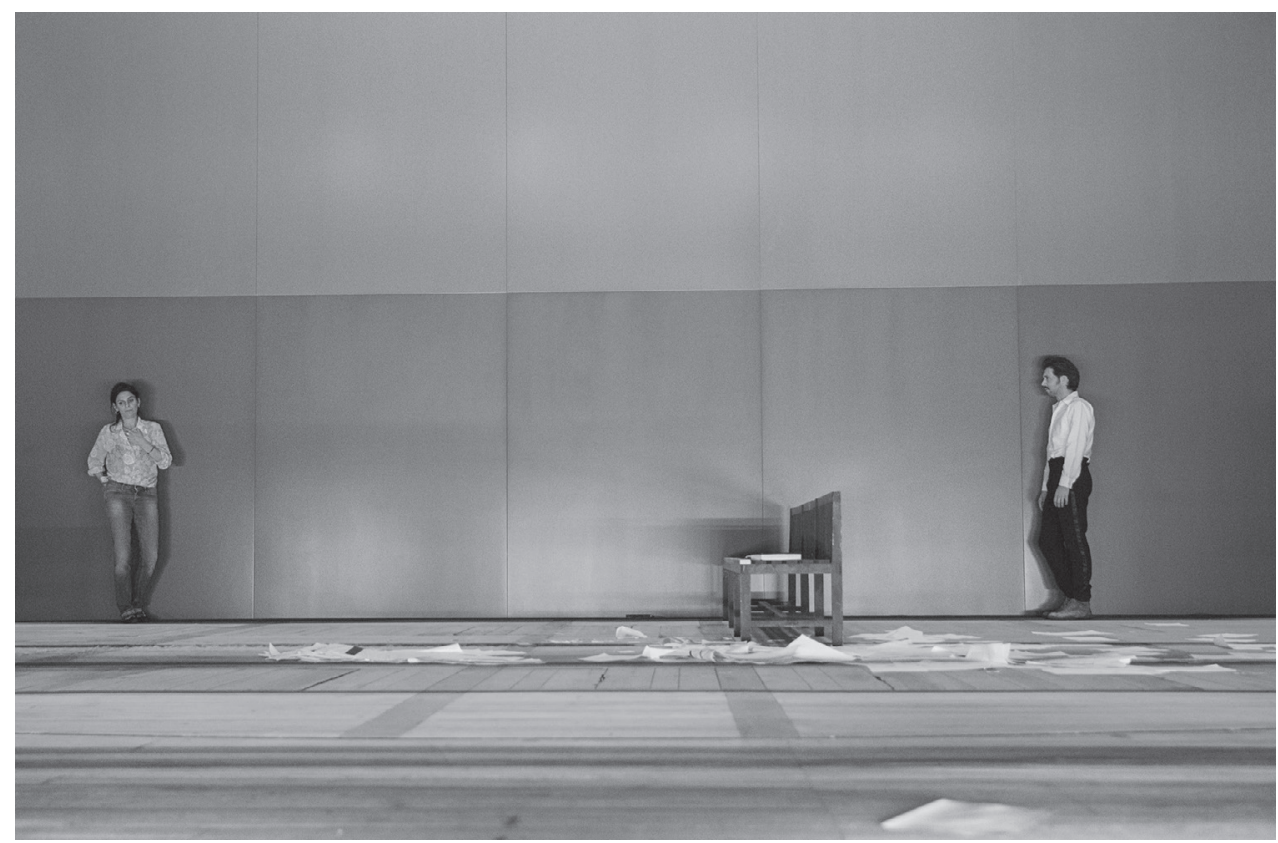

COMO ELA MORRE, DE TIAGO RODRIGUES, ENC. ISABEL ABREU, FRANK VERCRUYSSEN, JOLENTE DE KEERSMAEKER, PEDRO GIL E TIAGO RODRIGUES, 2017, TG STAN E TEATRO NACIONAL D. MARIA II (JOLENTE DE KEERSMAEKER, PEDRO GIL), [F] FILIPE FERREIRA 
apenas, que tudo tenha de estar em permanente circulação. Porque, sendo assim, esse teatro, essa circulação vivem de quê? Do trabalho dos artistas. Imagina que todos os artistas agora diziam: «Só faço vinte dias, pelo menos.» Alguma coisa tinha de mudar.

A máquina avariava, porque obviamente é necessário mais dinheiro para que os artistas possam ter espaços. Porque o que é preciso é mais espaço físico. É o espaço que vai possibilitar esse tempo para todos. Outra solução seria o Estado começar a financiar projectos que não aconteçam necessariamente nos seus próprios teatros, que parasse de se autofinanciar obrigatoriamente. Eu, se tivesse proposto, em vez do São Luiz, fazer o Don Juan em plena relva da Alameda, ou na Latoaria, a probabilidade de a Direcção-Geral das Artes não me apoiar era muito elevada. Outra solução, que há anos está em cima da mesa, seria mais dinheiro para que os criadores pudessem criar e programar teatro em alguns dos muitos e renovados cineteatros que existem espalhados pelo país.

\section{Podem ter outros modelos, podem ter um modelo rotativo. Podes estar ali dois anos.}

Pode ser um projecto de dois, três, cinco anos. A vida pode ser hoje mais veloz, mas tem de continuar a ser vida. A dificuldade está em continuar o trabalho, em continuar o discurso com aquela pessoa. Tivemos um projecto feliz. Ainda agora acabámos a carreira em Lisboa do Don Juan, na segunda-feira seguinte teria começado a ensaiar outra coisa com as mesmas pessoas. Faz sentido, não? Porque nós temos um património adquirido que em muito ultrapassa o espectáculo. Temos uma riqueza difícil de verbalizar, uma dinâmica aquecida, um saber que alcançámos, que é uma pena de novo deitar fora. O que seria a peça seguinte, que nós, as mesmas pessoas, faríamos, logo a seguir? Poderia ser uma grande merda, mas a questão é: eu não sei o que seria porque, na verdade, nunca vivi isso. Muita gente o faz e sempre o fez, eu e muita gente da minha geração é que não. $\mathrm{E}$ acho que isso pode ser mesmo fantástico, continuar o diálogo, continuar a discussão, mas é logo a seguir, não é três anos depois.

Mas isso também é uma consequência dessa flexibilização do trabalho, não é, dessa precariedade? 
Acho fascinante a criação contemporânea, aquilo que fazemos em dois meses, para não dizer menos, em que por vezes todo um edifício é erigido do zero. É que não é só a dramaturgia, o texto, o decorar, a cenografia, os figurinos, a luz - é tudo, é a relação das pessoas, é toda uma forma de trabalhar, a forma de estar em cena, é toda uma logística. E acreditamos sempre que aquela pessoa com quem trabalhei há três anos e com quem fui feliz... que esse diálogo vai continuar agora. É bom que forçosamente continue porque temos um espectáculo para fazer, mas há três anos que não sei o que se passa dentro da cabeça daquela pessoa...

Também já não fazemos propriamente vida de café, não é? Como se diz que outros artistas noutros tempos faziam. Tertúlias em que a conversa podia continuar. O Facebook até poderia servir para isso, mas nem para isso serve. Limitamo-nos a ver os espectáculos uns dos outros e isso é já uma forma de nos mantermos ligados, mas não há nada como trabalhar, como estar na sala de ensaios a fazer aquilo que gostamos de fazer, a criar, a ensaiar e a fazer espectáculos. Continuar a discussão é um desafio do futuro.

Mas atenção, se perguntarmos a um actor: «Queres estar comigo nos próximos dois anos?», com todas as condições de trabalho necessárias, não é evidente que aquele actor de que eu tanto gosto me diga que sim. Por causa daquilo que pode estar a perder. Há uns anos, eu teria dito não. Há uns anos, era esta descontinuidade que me alimentava, hoje sinto que é a continuidade. 